BRUNA ESTER FERREIRA DE FARIA

\title{
PRODUÇÃO E CARACTERIZAÇÃO DE NANOPARTÍCULAS DE PRATA ESTABILIZADAS COM POLISSACARÍDEOS DA GOMA DO CAJUEIRO: PERSPECTIVAS NA PAPILOSCOPIA FORENSE
}




\section{PRODUÇÃO E CARACTERIZAÇÃO DE NANOPARTÍCULAS DE PRATA ESTABILIZADAS COM POLISSACARÍDEOS DA GOMA DO CAJUEIRO: PERSPECTIVAS NA PAPILOSCOPIA FORENSE}

Dissertação apresentada à Faculdade de Medicina/UnB, como parte dos requisitos para obtenção do título de Mestre em Ciências Médicas.

Orientadora: Prof ${ }^{a}$. Dra. Selma Aparecida Souza Kückelhaus

UNIVERSIDADE DE BRASÍLIA

FACULDADE DE MEDICINA PROGRAMA DE PÓS-GRADUAÇÃO EM CIÊNCIAS MÉDICAS 
Faria, Bruna Ester Ferreira de.

Produção e caracterização de nanopartículas de prata estabilizadas com polissacarídeos da goma do cajueiro: perspectivas na papiloscopia forense. / Bruna Ester Ferreira de Faria; orientadora Dra. Selma Aparecida Souza Kückelhaus.-Brasília, 2016.

$64 \mathrm{f}$.

Dissertação (Mestrado em Ciências Médicas - Área de concentração: A morfologia aplicada às Ciências Forenses) -Faculdade de Medicina da Universidade de Brasília.

1. Impressão digital latente. 2. Nanopartícula de prata. 2. Suporte poroso. 4. Goma do cajueiro. 5. Toxicidade. I. Título. 


\title{
PRODUÇÃO E CARACTERIZAÇÃO DE NANOPARTÍCULAS DE PRATA ESTABILIZADAS COM POLISSACARÍDEOS DA GOMA DO CAJUEIRO: PERSPECTIVAS NA PAPILOSCOPIA FORENSE
}

\begin{abstract}
Dissertação apresentada à Faculdade de Medicina/UnB, como parte dos requisitos para obtenção do título de Mestre em Ciências Médicas.
\end{abstract}

Aprovada em Brasília, em 29/02/2016.

BANCA EXAMINADORA

Prof $^{a}$. Dra. Selma Aparecida Souza Kückelhaus Universidade de Brasília

Prof. Dr. Rafael Perseghini Del Sarto

Centro Universitário do Distrito Federal - UDF

Polícia Civil do Distrito Federal - PCDF 
Dedico este trabalho aos colegas peritos em papiloscopia, que exercem suas atividades com dedicação e afinco e buscam na Ciência a solução para as necessidades da sociedade. 
"Você é aquilo que ninguém vê. Uma coleção de histórias, estórias, memórias, dores, delícias, pecados, bondades, tragédias, sucessos, sentimentos e pensamentos. Se definir é se limitar. Você é um eterno parênteses em aberto, enquanto sua eternidade durar." 


\section{AGRADECIMENTOS}

Agradeço a Deus, por tornar esse sonho realidade e me proporcionar vencer meus limites com força e determinação. À Nossa Senhora, por me amparar e ser exemplo de mulher de fé e esperança.

À Professora Dra. Selma Aparecida Souza Kückelhaus, agradeço por ter acreditado em meu potencial, mesmo quando nem eu mesma mais acreditava. Agradeço por ter me incentivado e compreendido nos momentos árduos, além de ter transmitido empolgação, entusiasmo e ensinamentos científicos preciosos.

Ao programa de Pós-Graduação em Ciências Médicas da Universidade de Brasília, aos professores que contribuíram na construção do conhecimento e aos servidores, por seu apoio e solicitude, especialmente ao Secretário Gledson Alessandro da Silva e aos colegas discentes de curso que partilharam etapas dos estudos e contribuíram com a minha formação.

À Polícia Civil do Distrito Federal, ao Departamento de Polícia Técnica e ao Instituto de Identificação, pela constante busca pelo aprimoramento das atividades em perícia papiloscópica, por meio do incentivo à pesquisa acadêmica.

Aos amigos Papiloscopistas Policiais Me. Rodrigo Meneses de Barros, Me. Leila Lopes Mizokami, Me. Lara Rosana Vieira Silva, Me. Paola Rabello Vieira, Me. Rodrigo Dutra Silveira Monteiro e Dr. Rafael Perseghini Del Sarto, pelo incentivo, amizade e contribuição técnica no decorrer da pesquisa.

Aos amigos Papiloscopistas Policiais Petterson Vitorino de Morais, Vanusa Venancio Bento Lira, Thalyta Oliveira, Laura Patrício, Maurícia Daniela Meireles, Luana Deuzirée Batista e Perito Criminal Vitor Leone Rossi, pela assistência técnica e sugestões. Aos demais companheiros de trabalho, pelo carinho, apoio e compreensão das demandas decorrentes da pesquisa.

Aos colegas do Laboratório de Biotecnologia da UFPI, campus de Parnaíba, e do Laboratório de Biologia Celular - IB/UnB, pela contribuição técnica-operacional. Aos colegas do Instituto de Física da USP de São Carlos, pela parceria e colaboração nas etapas de síntese e caracterização das amostras.

Aos professores Dra. Carla Eiras, Dr. José Roberto Souza Almeida Leite e Dr. José Raimundo Corrêa, por todo conhecimento e experiência transmitidos com 
empenho e dedicação. À assistente Mariana Vieira Oliveira, por sua amizade, interesse e fundamental auxílio durante a realização do estudo. Aos colegas farmacêuticos e amigos, Adriana Delcy de Oliveira e Prof. Dr. Edemilson Cardoso da Conceição. À primeira, por sua disponibilidade, companheirismo, apoio e sintonia. Ao segundo, por seus ensinamentos e por estimular e acreditar em meu potencial para a pesquisa científica nas diferentes áreas profissionais nas quais atuei. Aos professores do Laboratório de Farmacologia Molecular, Dr. Luiz Alberto Siemoni e Dr. Francisco Neves, pelos inestimáveis aprendizados adquiridos durante a iniciação científica, os quais representaram importância ímpar para a execução do presente estudo.

Ao meu pai, Jeuvani Marques de Faria, que tanto me motivou a iniciar e persistir na busca pelo conhecimento e crescimento profissional e acadêmico e, mesmo não tendo podido participar do desfecho da presente pesquisa, foi um dos meus maiores incentivadores e terá o lugar de inspiração no meu coração sempre guardado para si, com muita honra, por sua inteligência, sabedoria e perspicácia. À minha mãe, Maria Teresinha Ferreira de Faria, companheira de todas as horas, portadora de palavras de otimismo e transmissora de gestos inigualáveis de amorosidade e paciência. Ao meu irmão e amigo, Jeuvani Marques de Faria Júnior, que tanto me estimulou e se alegrou com minhas conquistas. À minha querida cunhada e amiga Jéssica Maria Ribeiro, pela caminhada comigo, principalmente nas maiores dificuldades. À minha madrinha Maria Afonsina Ferreira Matos, ícone de inteligência e de busca pelo saber, que naturalmente me influenciou. À minha tia Marluci Aparecida Ferreira, que tanto vibrou com minhas superações. Aos meus avós Adélia Ferreira Porto e José Ferreira Sobrinho, exemplos de garra, força e sabedoria, que tanto se orgulham das minhas vitórias. A todos os familiares e amigos que estiveram presentes nessa minha jornada, pela motivação e empenho em me entender e auxiliar nas dificuldades.

A todos, meu especial carinho e profunda gratidão. 


\section{RESUMO}

No âmbito da perícia forense, o método papiloscópico pode ser empregado em diferentes situações para produção de provas, mediante o confronto de impressões digitais com padrões biométricos armazenados em bancos de dados oficiais. A qualidade da revelação das impressões latentes depende em grande parte da superfície de aposição, sendo que as superfícies porosas, em geral, apresentam elevado grau de dificuldade. Estudos demonstram que formulações nanoparticuladas podem ser promissoras na revelação de impressões digitais latentes em superfícies porosas. Tendo em vista a vasta biodiversidade brasileira, buscou-se na resina extraída do tronco do cajueiro (Anacardium occidentale L., Anacardiaceae), dadas suas propriedades na formação de coloides, a formulação de nanopartículas com potencial na revelação de impressões latentes. O objetivo deste trabalho foi caracterizar e avaliar o efeito de nanopartículas de prata produzidas com polissacarídeos hidrofílicos extraídos da goma do cajueiro com ou sem adição de agente redutor forte, em sistema biológico, para determinar a segurança aos usuários e, preliminarmente, seu potencial como agente revelador de impressões digitais latentes. As nanopartículas de prata estabilizadas com polissacarídeos de goma de cajueiro foram preparadas na ausência (síntese verde) ou presença (via úmida) do agente redutor borohidreto de sódio $\left(\mathrm{NaBH}_{4}\right)$. Os nanocompostos produzidos pela síntese verde foram denominados AgNP-CG e, pela via úmida, $\mathrm{AgNP}_{-} \mathrm{NaBH}_{4}$. Nesse estudo, as nanopartículas foram caracterizadas por microscopia eletrônica de transmissão, a fim de determinar o diâmetro e forma dessas espécies. Para avaliar seu potencial como agente revelador de impressões latentes, um doador produziu impressões digitais em superfície porosa e não porosa (papel alcalino branco e lamínulas de vidro, respectivamente). A toxicidade in vitro foi testada em células peritoneais de camundongos Swiss $(\mathrm{n}=8)$ e, in vivo, por exposição tópica do condutor do ensaio, a fim de avaliar a viabilidade de uso do sistema nanoparticulado na rotina pericial. Os resultados mostraram que o aumento do diâmetro das nanopartículas é diretamente proporcional ao aumento da concentração de goma de cajueiro (regressão linear, $p=0,038 ; r^{2}=0,093$ ). Dentre as amostras sintetizadas com borohidreto de sódio, somente a de menor concentração desse redutor promoveu revelação de impressões digitais no papel branco. Para as amostras obtidas por síntese verde, todas foram capazes de revelar as impressões no suporte primário poroso, embora algumas tenham revelado somente com posterior imersão em água deionizada. A revelação com AgNP-CG 3 mg/L e AgNPCG $5 \mathrm{mg} / \mathrm{L}$ em lamínulas de vidro demonstrou a capacidade de revelação de impressões digitais também em superfície de característica não porosa. Dentre as nanopartículas avaliadas nos ensaios de toxicidade in vitro, apenas a menor concentração, via síntese com $\mathrm{NaBH}_{4}(0,5 \mathrm{mg} / \mathrm{mL})$, não afetou o percentual de redução do MTT das células peritoneais (teste t pareado, $p>0,05$ ), enquanto que as demais (AgNP-CG 2, 3 ou $4 \mathrm{mg} / \mathrm{mL}$ ) reduziram esse percentual (teste t pareado ou 
Wilcoxon, $p<0,05)$, quando comparados ao controle. $O$ ensaio de toxicidade in vivo demonstrou ausência visual de injúrias à epiderme. Os resultados obtidos nesse estudo demonstraram potencial biotecnológico dos sistemas nanoparticulados como agentes reveladores de impressões digitais latentes sobre superfície porosa, bem como para aplicação ocupacionalmente segura para os peritos.

Palavras-chave: Impressão digital latente. Nanopartícula de prata. Suporte poroso. Goma do cajueiro. Toxicidade. 


\begin{abstract}
In forensics, the fingerprint analysis is largely employed in different situations to produce evidence considering biometric templates stored in databanks of law enforcement agencies. The quality of the development of latent prints depends largely on the surfaces where the fingerprints are produced, in which the porous surfaces show higher difficulties. Studies have demonstrated that silver nanoparticles formulations may be promising as fingerprints developers. In view of the vast Brazilian biodiversity, the resin extracted from the cashew tree trunk (Anacardium occidentale L., Anacardiaceae) has proved to be of great interest, on account of its properties that holds the synthesis of silver colloids with nanometer dimensions, that may be potential in developing latent fingerprint. Silver nanoparticles cashew tree gum-stabilized were prepared upon absence (green synthesis) or presence (wet via) of the strong agent sodium borohydride $\left(\mathrm{NaBH}_{4}\right)$. The nanocomposites produced by green synthesis were designed as AgNP-CG and, by wet via, AgNP-NaBH ${ }_{4}$. In this study, the silver nanoparticles were characterized by transmission electron microscopy to determine their diameter and morphology. In order to evaluate the potential as a fingerprint developer, one donor has produced latent prints on porous and nonporous surface (alkaline white paper and glass cover slips, respectively). In vitro toxicity was assessed in cultures of peritoneal cells of Swiss mice $(n=8)$, and in vivo by topical exposure of the assay conductor, to evaluate application feasibility of the nanoparticles in expert routine. Results have shown that the increase in diameter of the nanoparticles is directly proportional to the increase of cashew gum concentration (linear regression, $p=0,038 ; r^{2}=0,093$ ). Considering samples synthesized with sodium borohydride, only the one with the lowest concentration of this reducing agent developed fingerprints over white paper. For samples obtained by green synthesis, all of them were able to develop fingerprints on porous support, although some have developed only after further immersion in deionized water. The results with AgNP-CG $3 \mathrm{mg} / \mathrm{mL}$ and GCAgNP $5 \mathrm{mg} / \mathrm{mL}$ on glass slides exhibited the development ability also on nonporous surfaces. Between the samples analyzed, only the lowest dilution of nanoparticles suspension synthesized with sodium borohydride $0.5 \mathrm{mg} / \mathrm{mL}$ did not affect the viability of peritoneal cells (paired t test, $p>0,05$ ). However, the other ones (AgNP-CG 2, 3 or $4 \mathrm{mg} / \mathrm{mL}$ ) did reduced this percentage (paired $\mathrm{t}$ test or Wilcoxon, $\mathrm{p}<0,05)$ when compared to the control group. Thereby, the toxicity in vivo assay has demonstrated no visible injuries to the epidermis. The results have shown that tested nanoparticle formulations have biotechnological potential for use as developing agents for porous supports, as well they are occupationally safe to the fingerprints experts.
\end{abstract}

Keywords: Latent fingerprints. Silver nanoparticles. Porous surface. Cashew tree gum. Toxicity. 


\section{SUMÁRIO}

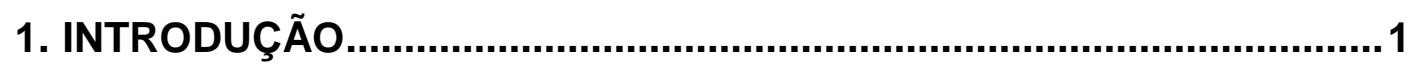

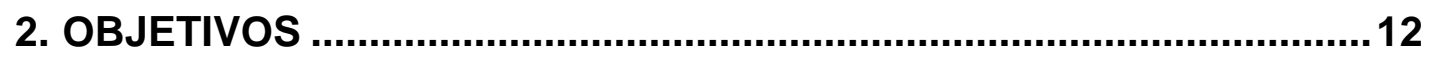

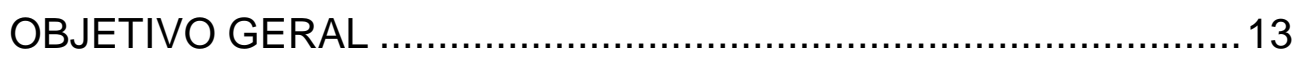

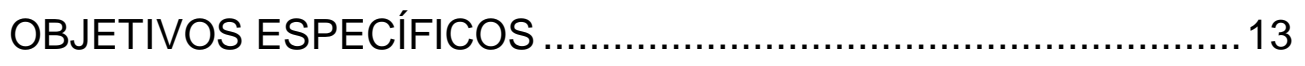

3. MATERIAIS E MÉTODOS................................................................ 14

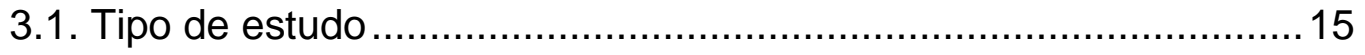

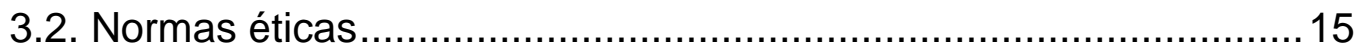

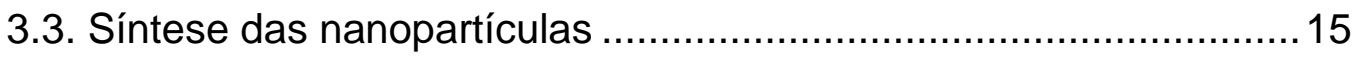

3.4. Caracterização morfológica das nanopartículas ............................ 17

3.5. Produção das impressões digitais latentes em superfície

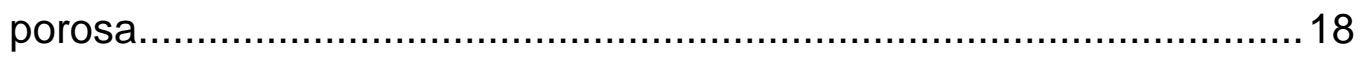

3.6. Revelação das impressões digitais latentes em superfície porosa

3.7. Produção e revelação das impressões digitais latentes em superfície

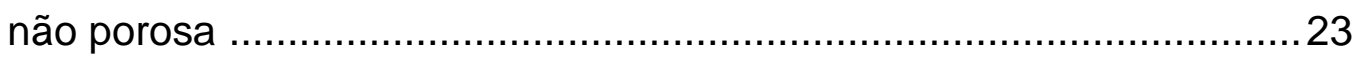

3.8. Avaliação de citoxidade das nanopartículas ..................................24

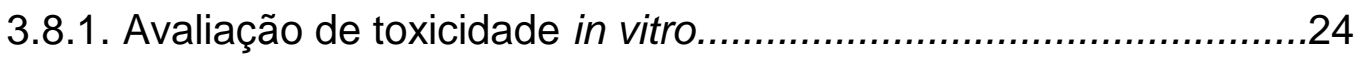

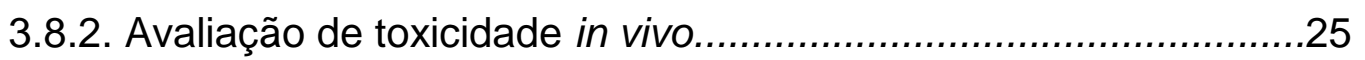

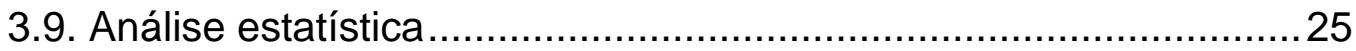

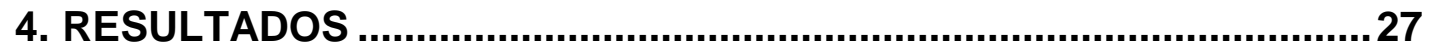

4.1. Caracterização morfológica das nanopartículas ............................28

4.2. Revelação de impressões digitais latentes .....................................31

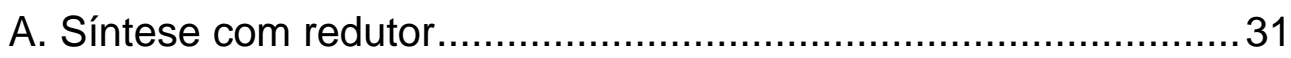

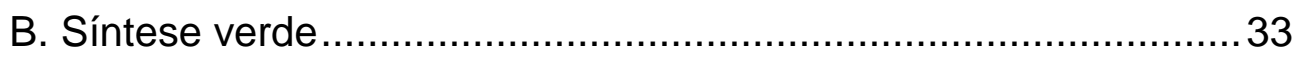

4.3. Avaliação de citoxicidade ........................................................ 34

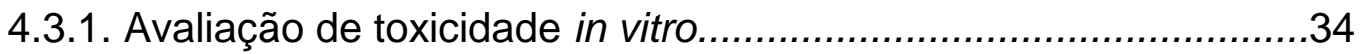

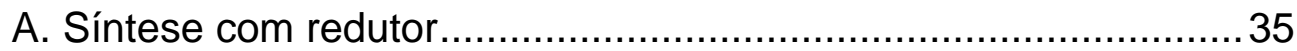

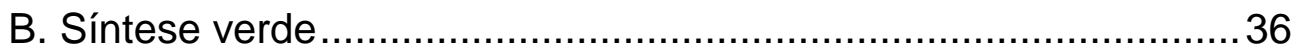

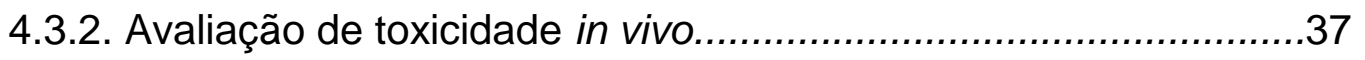

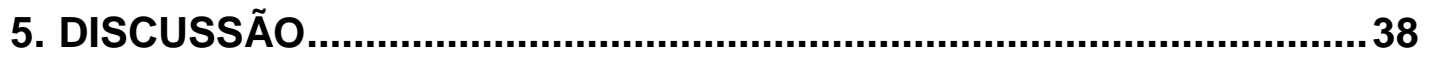

5.1. Caracterização morfológica das nanopartículas .............................39 
5.2. Revelação de impressões digitais latentes ...............................4 42

5.3. Avaliação de citoxicidade ..................................................... 48

5.3.1. Avaliação de toxicidade in vitro................................................48

5.3.2. Avaliação de toxicidade in vivo............................................49

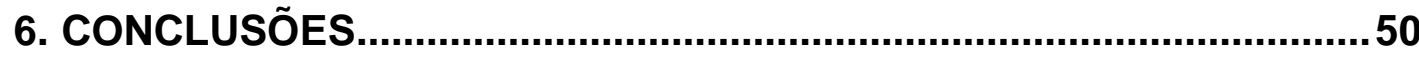

7. LIMITAÇÕES E PERSPECTIVAS ................................................... 52

REFERÊNCIAS BIBLIOGRÁFICAS ....................................................54

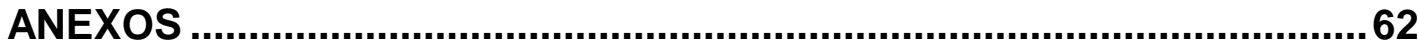

ANEXO A. Autorização do Comitê de Ética em Pesquisa em Seres Humanos 63

ANEXO B. Autorização do Comitê de Ética no Uso de Animais CEUA/FM/UnB .64 


\section{LISTA DE ILUSTRAÇÕES}

Figura 1. Características gerais da goma do cajueiro (Anacardium occidentale);(A) goma do cajueiro purificada; (B) esquema estrutural da goma do cajueiro. 8

Figura 2. Representação do mecanismo de estabilização por forças eletrostáticas. 9

Figura 3. Representação esquemática do efeito eletrostérico em sistemas coloidais estabilizados por macromoléculas. A área em vermelho destaca o efeito de impedimento estérico, enquanto a seta dupla esquematiza a repulsão eletrostática entre as cargas negativas 10

Figura 4. Fotografias das suspensões de AgNP sintetizadas com diferentes concentrações de (A) agente redutor borohidreto de sódio; (B) goma de cajueiro.

Figura 5. (A) Partes circulares do suporte poroso obtidas da hemiparte esquerda de impressão digital reveladas com as amostras de nanopartículas; (B) Hemiparte direita utilizada como controle positivo, revelada por aspersão com solução de ninidrina. Imagens obtidas com Câmera Nikon D60® sem ampliação 20

Figura 6. Representação esquemática dos procedimentos empregados na revelação de impressões latentes em suporte poroso. (A) 1․ 30 minutos de imersão dos suportes na suspensão de nanopartículas; $2^{\circ}$. secagem a $\pm 25^{\circ} \mathrm{C}$; 3 . registro fotográfico das impressões reveladas. (B) 1․ 30 minutos de imersão dos suportes na suspensão de nanopartículas; $2^{\circ}$. lavagem em água deionizada por um minuto; $3^{\circ}$. secagem a $\pm 25^{\circ} \mathrm{C}$; $4^{\circ}$ registro fotográfico. 22

Figura 7. Representação esquemática dos procedimentos empregados na revelação de impressões latentes em lamínulas de vidro. (1ํ) 15 minutos de 
imersão dos suportes na suspensão de nanopartículas; ( $\left.2^{\circ}\right)$ lavagem em água deionizada por 5 minutos; (3을 secagem à temperatura ambiente; (4ํ) visualização e registro fotográfico por microscopia eletrônica de varredura (MEV)

Figura 8. Distribuição do diâmetro das nanopartículas. Amostras sintetizadas com agente redutor $\left(\mathrm{NaBH}_{4}\right)$ nas concentrações de $0,5 \mathrm{mg} / \mathrm{mL}$ ou $1,0 \mathrm{mg} / \mathrm{mL}$ e amostras obtidas por síntese verde (estabilizadas apenas com goma do cajueiro) nas concentrações de $1,0 \mathrm{mg} / \mathrm{mL}, 2,0 \mathrm{mg} / \mathrm{mL}, 3,0 \mathrm{mg} / \mathrm{mL}, 4,0 \mathrm{mg} / \mathrm{mL}$ ou $5,0 \mathrm{mg} / \mathrm{mL}$. Os diâmetros das nanopartículas aumentam com a maior concentração de borohidreto de sódio (Wilcoxon, $p=0,037$ ) ou relação diretamente proporcional entre o diâmetro das nanopartículas e o aumento da concentração de goma de cajueiro (Regressão linear, $p=0,038$ ). Estão representadas as medianas, quartis, valores máximos e mínimos. 29

Figura 9. Eletromicrografias de transmissão das nanopartículas obtidas das amostras sintetizadas com (A) $0,5 \mathrm{mg} / \mathrm{mL}$ ou (B) $1,0 \mathrm{mg} / \mathrm{mL}$ de agente redutor $\left(\mathrm{AgNP}_{\mathrm{NaBH}}\right)_{4}$ e obtidas pela síntese verde (AgNP-CG) com diferentes concentrações da goma do cajueiro (C) $1,0 \mathrm{mg} / \mathrm{mL}$, (D) $2,0 \mathrm{mg} / \mathrm{mL}$, (E) 3,0 $\mathrm{mg} / \mathrm{mL}$, (F) $4,0 \mathrm{mg} / \mathrm{mL}$ ou (G) $5,0 \mathrm{mg} / \mathrm{mL}$. Escala de $50 \mathrm{~nm}$. 30

Figura 10. Eletromicrografias de transmissão de novas amostras de nanopartículas obtidas com diferentes concentrações da goma do cajueiro (AgNP-CG) (A; escala de $1 \mu \mu \mathrm{m}) ; \quad(B ; \quad$ escala de 100 $\mathrm{nm})$ 31

Figura 11. Fotografias da revelação de impressões digitais em papel sulfite branco. (A) imersão em suspensão de AgNP-NaBH ${ }_{4} 0,5 \mathrm{mg} / \mathrm{mL}$; (B) imersão em suspensão de $A g N P-N B_{4} H_{4}, 5 \mathrm{mg} / \mathrm{mL}$ com posterior lavagem em água deionizada; (C) imersão em suspensão de AgNP-CG 1,0 mg/mL com posterior lavagem em água deionizada; (D) imersão em suspensão de AgNP-CG 2,0 $\mathrm{mg} / \mathrm{mL}$ com posterior lavagem em água deionizada; $(E)$ imersão em suspensão de AgNP-CG 3,0 mg/mL com posterior lavagem em água deionizada; $(F)$ imersão em suspensão de AgNP-CG 4,0 mg/mL; (G) imersão em suspensão 
de AgNP-CG 4,0 mg/mL com posterior lavagem em água deionizada; $(H)$ imersão em suspensão de AgNP-CG $5,0 \mathrm{mg} / \mathrm{mL}$. As imagens foram obtidas com Câmera Nikon D60® sem ampliação.

Figura 12. Eletromicrografias obtidas por microscopia eletrônica de varredura da estrutura do papel sulfite branco empregado nos experimentos de revelação de impressões digitais. Escala: A $-1 \mathrm{~mm}$, B $-100 \mu \mathrm{m}, \mathrm{C}-10$ $\mu \mathrm{m}$

Figura 13. Eletromicrografias obtidas por microscopia eletrônica de varredura da revelação de impressões digitais em lamínulas de vidro com diferentes amostras de nanopartículas. (A) AgNP-CG $3 \mathrm{mg} / \mathrm{mL}$ e (B) AgNP-CG $5 \mathrm{mg} / \mathrm{mL}$. Aumento de 16x e 15x, respectivamente.

Figura 14. Novas amostras de AgNP-CG (A) e (B) resultado positivo de revelação de impressões digitais em papel pardo. 34

Figura 15. Percentual de redução do MTT por macrófagos peritoneais de camundongos Swiss ( $n=8)$ após incubação com diluições de $10 \%, 25 \%$ ou $50 \%$ de amostra de AgNP-NaBH $4,5 \mathrm{mg} / \mathrm{mL}$. A amostra, nas diluições $25 \%$ ou $50 \%$, reduziu a viabilidade dos macrófagos quando comparado ao controle (meio RPMI) (teste $t$ pareado, $p=0,022$ e $p<0,0001$, respectivamente). A menor diluição de $\mathrm{AgNP}-\mathrm{NaBH}_{4}(10 \%)$ não afetou o percentual de macrófagos viáveis na comparação com o controle $(p>0,05)$. Estão representadas as medianas, quartis, valores máximos e mínimos.

Figura 16. Percentual de redução do MTT por macrófagos peritoneais de camundongos Swiss $(n=8)$ após incubação com diluições seriadas de $10 \%$, $25 \%$ ou $50 \%$ da suspensão de nanopartículas sintetizadas com 2 (A), 3 (B) ou 4 (C) $\mathrm{mg} / \mathrm{mL}$ de goma de cajueiro. As três amostras, nas diferentes diluições, causaram redução no percentual de redução do MTT $(p<0,05)$. Estão representadas as medianas, quartis, valores máximos e mínimos. 37

Figura 17. Representação da estrutura química da celulose .43 


\section{LISTA DE TABELAS}

Tabela 1. Concentrações das soluções de nitrato de prata, borohidreto de sódio e polissacarídeos do cajueiro utilizadas na síntese das diferentes concentrações de amostras de nanopartículas (AgNP-NaBH 4 e AgNP-CG)... 16

Tabela 2. Procedimentos empregados nos experimentos de revelação de impressões latentes em suporte poroso com diferentes concentrações de AgNP-NaBH $H_{4}$ e AgNP-CG. 21

Tabela 3. Medianas dos diâmetros das nanopartículas para as amostras sintetizadas com agente redutor ( $\left.\mathrm{AgNP}-\mathrm{NaBH}_{4}\right)$ e para as amostras obtidas por síntese verde (AgNP-CG) .28

Tabela 4. Resultado dos testes de revelação em papel sulfite branco para as amostras sintetizadas com agente redutor $\left(\mathrm{AgNP}-\mathrm{NaBH}_{4}\right)$ ou para as amostras obtidas pela rota de síntese verde (AgNP-CG), com ou sem posterior imersão em água ultrapura 31

Tabela 5. Percentual de redução do MTT por macrófagos peritoneais de camundongos Swiss $(n=8)$ após incubação com diluições de 10\%, 25\% e 50\% de amostra de AgNP-NaBH $40,5 \mathrm{mg} / \mathrm{mL}$ ou de suspensões de nanopartículas sintetizadas com 2, 3 ou $4 \mathrm{mg} / \mathrm{mL}$ de goma de cajueiro 


\section{LISTA DE SIGLAS, SÍMBOLOS E ABREVIATURAS}

$\mathrm{Ag}^{+}$- Prata iônica

$\mathrm{AgNO}_{3}-$ Nitrato de prata

AgNP - Nanopartícula de prata

AgNP-CG - Nanopartícula de prata estabilizada com polissacarídeos da goma do cajueiro

AgNP-NaBH 4 - Nanopartícula de prata estabilizada com borohireto de sódio $\mathrm{Ag}^{\circ}$ - Prata metálica ou reduzida

AgPD - Revelador físico de prata

AuNP - Nanopartícula de ouro

AuNP-CG - Nanopartícula de ouro estabilizada com goma do cajueiro

CEP - Comitê de Ética em Pesquisa

CEUA - Comissão de Ética no Uso de Animais

CG - Goma do cajueiro

FM - Faculdade de Medicina

GIMP - GNU Image Manipulation Program

II-PCDF - Instituto de Identificação da Polícia Civil do Distrito Federal

MET - Microscopia eletrônica de transmissão

MEV - Microscopia eletrônica de varredura

MMD - Deposição múltipla de metais

MTT - Sal tetrazolium amarelo de MTT

$\mathrm{NaBH}_{4}-$ Borohireto de sódio

NP - Nanopartícula

$\mathrm{pH}--\log \left[\mathrm{H}^{+}\right]$

PVA - Álcool polivinílico

$r^{2}$ - Coeficiente de correlação

RPMI - Meio Roswell Park Memorial Institute

SD - Desvio padrão

SMD - Deposição de metal único

PBS - Solução Salina Fosfato Tamponada

UnB - Universidade de Brasília 
1. INTRODUÇÃO 
Mesmo com o advento da genômica, o uso das impressões papilares constitui uma das formas mais utilizadas para identificação humana, especialmente importante na determinação de autoria de crimes. A individualização humana por meio das características específicas (minúcias) presentes nos desenhos papilares na pele espessa (palmar e plantar) é objeto de estudo da Papiloscopia Forense (Ashbaugh 1999). Esses desenhos, quando na polpa digital, são também denominados datilogramas e resultam de uma complexa interação entre derme e epiderme, originando as cristas de fricção, as quais se projetam na pele espessa (Ashbaugh 1999; Kücken 2007).

Para fins de individualização humana, é suficiente a determinação das características específicas e individuais do datilograma (Budowle et al. 2006), uma vez que, considerando-se a gama de variáveis que contribuem para a sua formação, a probabilidade de que existam dois indivíduos com configurações exatamente iguais, mesmo em casos de gêmeos monozigóticos, tende a zero, conforme demonstrado em cálculos matemáticos (Kücken 2007). Assim, esse método se destaca dentre os demais pela sua praticidade operacional, por seu baixo custo e por permitir altos níveis de confiabilidade (Mulawka 2014).

De acordo com o Princípio da Troca de Locard, o qual fundamenta a Criminalística, quando dois objetos entram em contato, ocorre transferência de material entre eles, mesmo que em quantidades ínfimas (Scott, 2009). Quando em contato com uma superfície, parte das substâncias encontradas na polpa digital é transferida, formando-se um fragmento de impressão digital sobre a superfície tocada. Se esses fragmentos não estiverem impregnados de substâncias que contrastem com o fundo, diz-se que houve a formação de uma impressão latente (Lee e Gaensslen 2001), necessitando do emprego de tratamentos específicos que permitam sua visualização, processo conhecido como "revelação" de impressões latentes (Champod et al. 2004). Os métodos empregados na revelação desses fragmentos dependem, sobretudo, das características do suporte onde foram apostos, dos componentes das impressões, bem como de fatores pós-transferência (Sears et al. 2012).

Destaca-se que, nas impressões latentes, há uma grande variedade de compostos, como contaminantes ambientais e uma complexa mistura de secreções das glândulas sudoríparas e sebáceas presentes na pele, formando o denominado filme ou emulsão hidrolipídica (Girod et al. 2012; Champod et al. 
2004; Choi et al. 2008). Estudos acerca da análise química de impressões latentes destacam a presença de gliceróis, ácidos graxos, colesterol e seus ésteres, bem como restos celulares, constituintes do filme hidrolipídico que recobre a epiderme, sintetizados pelas glândulas sebáceas (Milstone 2004; Girod et al. 2012). Esses componentes são encontrados nas impressões latentes, uma vez que são transferidos às regiões de pele espessa após o contato com outras partes do corpo, como a face e o couro cabeludo, locais onde há grande densidade de glândulas sebáceas (Archer et al. 2005; Croxton et al. 2010; Lim et al. 2011; Girod et al. 2012). Estão presentes, ainda, água e elementos inorgânicos, como cloreto, sódio, potássio e cálcio, além de outros produtos, como vitaminas, aminoácidos e proteínas (Terasawa et al. 2001, Ramotowski 2001; Ricci et al. 2007; Connatser et al. 2010; Girod et al. 2012).

Outros produtos de origem exógena (Ramotowski 2001), como os cosméticos (produtos para cabelo, perfumes e cremes para o corpo) (Mong et al. 1999; Croxton et al. 2010; Weyermann et al. 2011), nicotina (Benton et al. 2010), drogas de abuso (Day et al. 2004), poeira e esporos de bactérias (Ramotowski 2001; Tims et al. 2010) também já foram identificados nos resíduos de impressões latentes.

Ao serem transferidos para determinada superfície, esses constituintes passam por uma série de transformações, como a evaporação do componente aquoso, a oxidação de ácidos graxos e sua decomposição pela ação de microorganismos, o que pode influenciar a eficácia de técnicas de revelação baseadas em interação química (Archer et al. 2005).

O método papiloscópico pode ser empregado em diferentes situações, mediante o confronto de impressões digitais com os padrões datiloscópicos armazenados em bancos de dados oficiais. Para a identificação de cadáveres, é necessário que uma impressão digital seja gerada a partir das polpas digitais dos indivíduos, enquanto que, para a determinação de autoria de crimes, é necessário que os vestígios deixados em cenas de crime sejam revelados. Nesse segundo caso, as impressões digitais deixadas em uma determinada superfície por um indivíduo, ou seja, as impressões latentes, precisam ser reveladas e, 
posteriormente, confrontadas com os padrões datiloscópicos (Federal Bureau of Investigation 2001; Holder Jr et al. 2002).

Ressalta-se que a qualidade da revelação das impressões latentes depende em grande parte também da superfície de aposição (suporte primário). Nesse contexto, suportes de vidro, metal, madeira laqueada, superfícies plásticas, entre outras, apresentam vantagens, por serem de baixa ou nenhuma porosidade, de modo que o emprego de materiais simples e de baixo custo, como o pó regular, permite revelação bem-sucedida. Por outro lado, impressões digitais apostas sobre superfícies porosas como papel-moeda, madeira não envernizada e papéis em geral apresentam elevado grau de dificuldade para serem reveladas, em decorrência da porosidade e fragilidade desses materiais (Lee e Gaensslen, 2001).

Os métodos e tecnologias aplicadas à revelação de impressões latentes até o momento carecem de elucidação e muito do que se faz na perícia papiloscópica baseia-se em experiências e conhecimentos advindos de tentativa e erro e sem critério metodológico, o que explica a dificuldade de se obter referências bibliográficas especializadas.

Destaca-se que os agentes reveladores disponíveis para revelação de impressões digitais em suportes de característica porosa são a ninidrina e seus análogos (Lee e Gaensslen 2001), o diazafluoreno (Champod et al. 2004), os cristais de iodo submetidos à sublimação (Lee e Gaensslen 2001), o nitrato de prata (Daéid et al. 2009) e os reveladores físicos (Federal Bureau of Investigation 2001; Choi et al. 2008).

No Brasil, a ninidrina é o reagente comumente empregado para a revelação em papéis, mas apresenta limitações importantes, como o desenvolvimento de coloração de fundo, além de custo e toxicidade elevados (Lee e Gaensslen 2001). Já o diazafluoreno, apesar de possibilitar melhor qualidade de revelação, necessita de fonte de luz de alta potência e filtros apropriados, tornando seu uso mais dispendioso (Champod et al. 2004). Apesar de simples, a técnica que emprega vapores de iodo apresenta sérias 
desvantagens, como a toxicidade dos vapores produzidos e eficácia somente na revelação de impressões recentes (Lee e Gaensslen 2001).

Por sua vez, a prata é utilizada como revelador em suportes porosos mediante diversas técnicas. A aplicação de solução de nitrato de prata $\left(\mathrm{AgNO}_{3}\right)$, apesar de funcional e de baixo custo, apresenta desvantagens importantes, como corrosividade e toxicidade (Federal Bureau of Investigation 2001; Lee e Gaensslen 2001). O revelador físico de prata pode ser empregado após a revelação com ninidrina ou diazafluoreno, visando à amplificação da revelação por meio da interação com os componentes insolúveis em água, como as secreções sebáceas (Federal Bureau of Investigation 2001; Champod et al. 2004).

O uso de ouro coloidal no domínio das ciências forenses, como método de detecção de impressões digitais latentes, foi introduzido por G. Saunders em 1989, tendo sido denominado Deposição Múltipla de Metais (MMD), que se trata de uma evolução da técnica anterior. MMD consiste na imersão do objeto a ser tratado numa suspensão coloidal de ouro, seguida pela amplificação das impressões detectadas pelo do uso de um revelador físico de prata (Schnetz e Margot 2001). Todo esse processo evidencia a demora na preparação e aplicação, além do elevado custo dos reagentes envolvidos (Champod et al. 2004; Zhang 2007; Choi et al. 2008). Posteriormente, este método foi modificado por Schnetz e Margot (2001), controlando parâmetros de pH do ouro coloidal, tamanho e homogeneidade de distribuição das partículas, temperatura de revelação, concentrações das soluções de Tween 20 (tensoativo não iônico) e ouro coloidal. Foram obtidos o aumento da reatividade, devido à homogeneidade da solução e controle de pH, melhor qualidade de resolução da revelação, devido ao menor diâmetro das partículas de ouro produzidas, bem como maior seletividade na amplificação, devido a uma melhora no gatilho de nucleação do ouro coloidal, amplificado pela prata.

A vantagem do MMD sobre os demais métodos reside na sua sensibilidade, particularmente com impressões digitais envelhecidas, além de possibilitar utilização em diferentes superfícies porosas e não porosas (Stauffer et al. 2007). No entanto, requer um elevado número de banhos e reagentes, 
representando consumo de tempo e elevado custo. Recentemente, impressões digitais reveladas por esse método têm sido observadas por microscopia eletrônica de varredura (Zhang et al. 2007).

Uma abordagem diferenciada foi demonstrada em estudos de Sametband et al. (2007), em que a eficácia da utilização de nanopartículas de ouro foi avaliada na revelação de impressões produzidas em papel, utilizando como agente estabilizante o álcool polivinílico (PVA), polímero atóxico, porém, sintético (Berni Neto 2010; Khanna et al. 2005; Mbhele et al. 2003); nesse estudo, as nanopartículas de ouro foram usadas como adjuvantes na revelação de impressões latentes previamente submetidas ao revelador físico de prata.

Em que pese à disponibilidade de agentes reveladores para materiais porosos, ressalta-se que nenhum dos métodos disponíveis atende, por completo, aos requisitos de praticidade, rapidez e qualidade da revelação, associados a custos acessíveis e baixa toxicidade ocupacional e ambiental. Assume-se que os métodos baseados no emprego dos sais de prata, como vêm sendo empregados, apresentam baixa qualidade de revelação, causam coloração de fundo, são destrutivos e tóxicos, além de inviabilizar tratamentos adicionais (Federal Bureau of Investigation 2001). No entanto, considera-se a possibilidade de se utilizar os benefícios da prata na revelação de impressões latentes sob uma conformação que diminua ou elimine sua toxicidade, bem como seja capaz de aprimorar a qualidade da revelação. Uma alternativa para alcançar esse objetivo é a formulação nanoparticulada da prata, empregando-se materiais biocompatíveis e biodegradáveis, empregando-se a chamada "síntese verde" (Sharma et al. 2009; Parashar et al. 2011; Shameli et al. 2012) em que são utilizados diferentes agentes redutores naturais brandos, como fungos e bactérias (Sastri et al. 2003; Shahverdi et al. 2007; Fayaz et al. 2010), quitosana (Wei et al. 2009; Tran et al. 2010), extratos vegetais (Krishnaraj et al. 2010; Saxena et al. 2012), algas marinhas (Shukla et al. 2012; Venkatpurwar 2011) e exsudatos de plantas (Kora et al. 2010).

Por apresentarem dimensões em escala nanométrica (1 a 100 nm), as nanopartículas (NP) apresentam propriedades físicas e químicas diferentes das 
do material de origem, com uma porcentagem consideravelmente mais elevada de átomos em sua superfície, quando comparadas com partículas maiores (Choi et al. 2008). Devido ao seu empacotamento em nanopartículas, acredita-se que a prata permaneça em maior disponibilidade nos sítios de ação. Essas características possivelmente promovem uma melhor revelação empregando-se uma menor concentração do metal, em comparação com os demais métodos existentes (Becue et al. 2007), podendo reduzir, desse modo, a toxicidade inerente ao metal.

O uso de gomas naturais provenientes de exsudatos e extratos de plantas vem tomando grande impulso por suas múltiplas e lucrativas possibilidades na indústria. Nesse aspecto, destaca-se a resina extraída do cajueiro, espécie Anacardium occidentale L. (Anacardiaceae) (de Paula 1998). Devido à sua abundância no território nacional e à importância da cultura do cajueiro, especialmente no nordeste brasileiro, o conhecimento acerca das características da goma e as pesquisas realizadas sobre seu potencial biotecnológico despertam grande interesse científico (Sarubbo et al. 2000). Ainda, pode vir a ser exportado e, por possuir características semelhantes às da goma arábica, minimizar sobremaneira a onerosa importação desta última para o Brasil (Tadros et al. 2007).

Quando no estado sólido, a resina apresenta coloração âmbar, é inodora, insípida, atóxica, biodegradável e hidrofílica. Trata-se de um polímero natural de fonte renovável e sustentável, de baixo custo de extração, retirado do tronco do cajueiro e consiste em um exsudato heteropolissacarídico ácido ramificado. Do ponto de vista reológico (deformação e resistência), a goma do cajueiro assemelha-se a muitos polímeros sintéticos, provendo interesse tecnológico devido a sua biodegradabilidade e propriedades mecânicas. Quando solubilizada em água, desenvolve caráter aniônico, além de propriedades coloidais e de formar suspensões altamente viscosas, com funções espessantes, geleificantes, emulsionantes, estabilizantes e aglutinantes (Menestrina et al. 1998). Estruturalmente, a goma do cajueiro (CG) é constituída de unidades de b-Dgalactose $(72 \%)$, a-D-glicose (14\%), arabinose $(4.6 \%)$, ramnose $(3.2 \%)$ e ácido 
glicurônico (4.7\%) (Menestrina et al. 1998), como demonstrado na Figura 1.

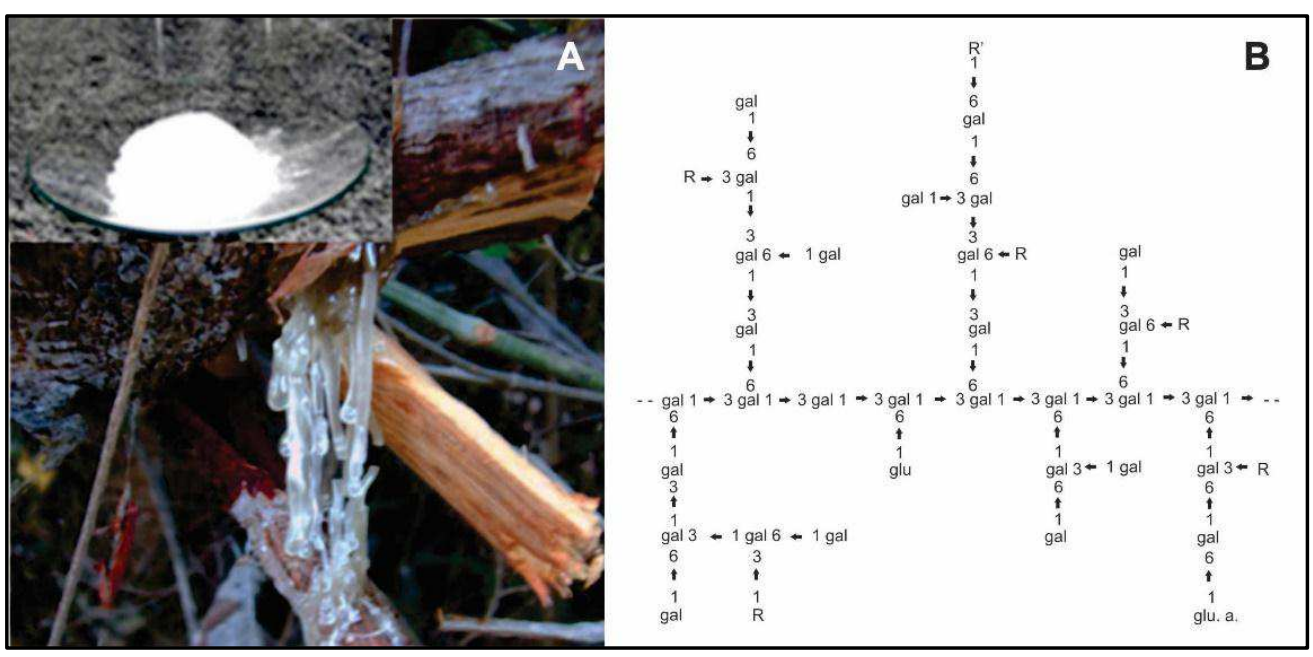

Figura 1. Em A, observa-se uma fotografia do caule do cajueiro (Anacardium occidentale) com exsudato que pode ser obtido de forma espontânea ou mediante corte no tronco, com destaque para a goma do cajueiro purificada no canto superior esquerdo (Fonte: Quelemes et al. 2013). Em B, observa-se o esquema estrutural da goma do cajueiro, sendo o radical $\mathrm{R}$ formado por $\mathrm{D}$-manose, L-ramnose, L-arabinose ou cadeias de arabinose com ligação 1,2 e o R' formado por D-glicose ou ácido D-glucurônico; Gal representa galactose (Fonte: adaptado de Menestrina et al. 1998).

O potencial das nanopartículas de prata (AgNP) na revelação de impressões digitais latentes baseia-se não somente na ação propriamente dita da prata, que naturalmente se impregna em compostos orgânicos, mas também na interação eletrostática dos polissacarídeos com os componentes secretados pelas glândulas sudoríparas, dada sua característica hidrofílica. Resultados recentes do nosso grupo de pesquisa demonstraram a influência de parâmetros de $\mathrm{pH}$, tempo de reação, temperatura e concentração da suspensão da goma do cajueiro nas características e estabilidade das nanopartículas de prata formadas (dados não publicados).

No caso de nanopartículas sintetizadas a partir da redução do metal na presença de $\mathrm{NaBH}_{4}$, uma das formas de atingir a estabilidade do sistema ocorre pela a adição em excesso de boroidreto de sódio, em relação ao sal de prata, uma vez que esse reagente atua simultaneamente como redutor dos íons prata e é também responsável pela estabilização das nanopartículas que se formam (Solomon et al. 2007). Parte do borohidreto de sódio é consumida na reação de 
redução de prata iônica a prata metálica, por meio da reação:

$$
\mathrm{AgNO}_{3}+\mathrm{NaBH}_{4} \rightarrow \mathrm{Ag}+1 / 2 \mathrm{H}_{2}+1 / 2 \mathrm{~B}_{2} \mathrm{H}_{6}+\mathrm{NaNO}_{3}
$$

Enquanto isso, o íon borohidreto sobressalente adsorve-se à superfície das nanopartículas do metal reduzido, fornecendo uma camada elétrica carregada negativamente e, por conseguinte, ocorre uma repulsão eletrostática que evita a agregação das estruturas (Solomon et al. 2007). Porém, a adição de um excesso ainda maior de boroidreto de sódio pode aumentar a força iônica do meio, facilitando a agregação das partículas. É importante destacar que o boroidreto de sódio é um agente redutor forte na presença de íons prata e, desta maneira, é necessário o resfriamento prévio da solução do redutor e a adição lenta da solução do sal de prata. Nesse caso, observa-se a formação de nanopartículas com diâmetros próximos a $12 \mathrm{~nm}$ (Solomon et al. (2007).

Um esquema da formação das camadas de íons boroidreto ao redor das nanopartículas de prata é mostrada na Figura 2.

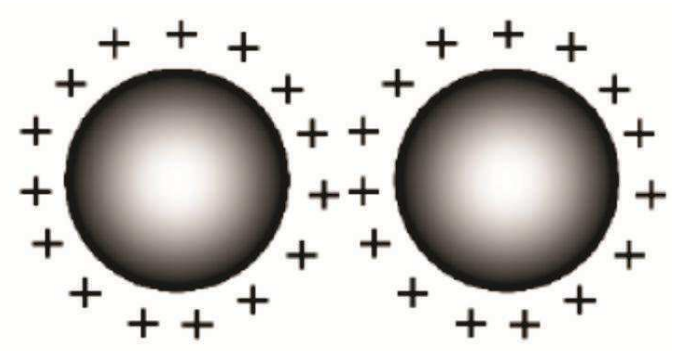

Figura 2. Representação do mecanismo de estabilização das nanopartículas por forças eletrostáticas. Fonte: adaptado de Berni Neto 2010.

Em geral, a energia favorável para o crescimento das partículas é fornecida pela formação do material em escala macroscópica; assim, a remoção dessa energia de ativação, pela diminuição da temperatura do sistema, interrompe o crescimento, permitindo um controle cinético mais preciso do tamanho dessas partículas. A interação eletrostática como mecanismo único para inibir o processo de agregação não é muito eficiente, já que esse artifício não apresenta resistência a mudanças em ampla faixa de pH (Berni Neto 2010).

Destaca-se que o polissacarídeo do cajueiro constitui um polieletrólito, ou seja, possui grupos carregados que promovem repulsão eletrostática. Porém, 
possuem também cadeias longas que se posicionam na superfície das NP, ocupando um espaço em seu entorno (Figura 3). Essas estruturas são responsáveis por um segundo mecanismo que leva à estabilidade em sistemas nanoparticulados, o efeito ou impedimento estérico, evitando ou minimizando a agregação (Melo Júnior et al. 2012; Caruso 2004; Goodwin 2004).

$\mathrm{Na}$ medida em que ocorre a aproximação de duas interfaces, ocorre a aproximação das cadeias poliméricas até a ocorrência de interpenetração entre as moléculas. Quanto mais próxima uma superfície da outra, menor o espaço existente para a acomodação das macromoléculas, constringindo o número de conformações possíveis para cada macromolécula (figura 3 - zona sombreada). Quanto maior a proximidade entre as partículas, maior a constrição imposta, e consequentemente, a entropia diminui, ocasionando o aumento da energia livre e tornando a aproximação termodinamicamente desfavorável, promovendo estabilidade à emulsão. Esses dois efeitos, em conjunto, constituem a estabilização eletrostérica, que ocorre para nanopartículas estabilizadas com polissacarídeos extraídos da goma do cajueiro (Caruso 2004; Goodwin 2004).

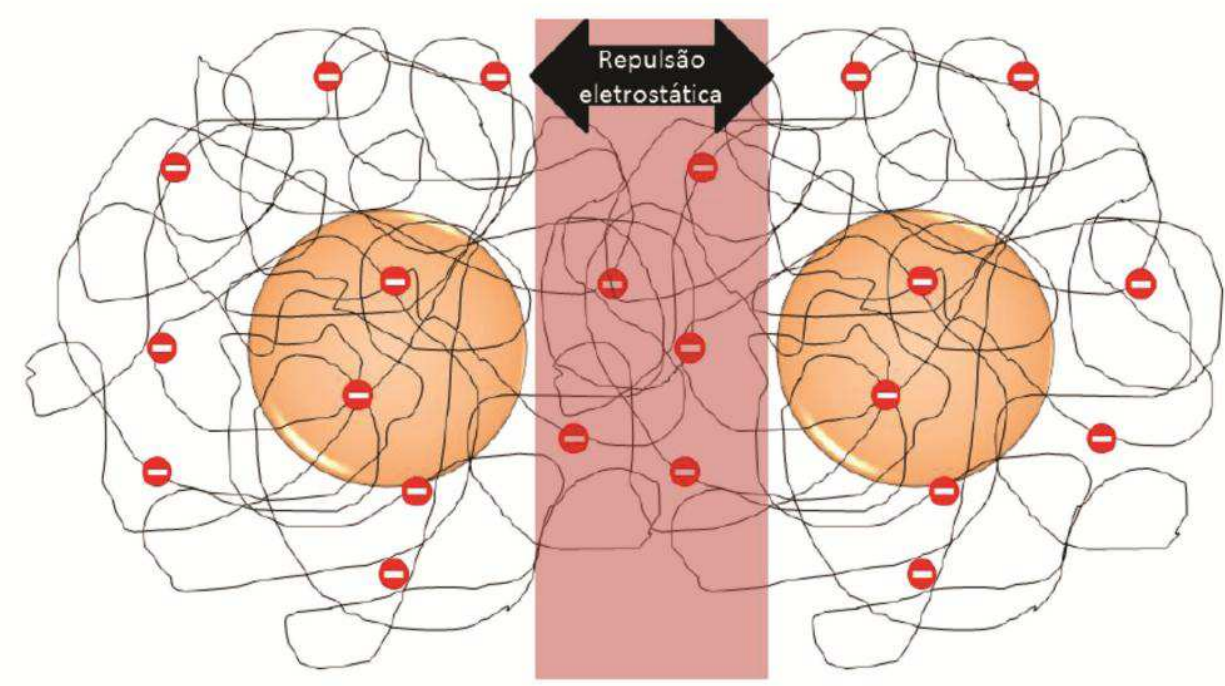

Figura 3. Representação esquemática do efeito eletrostérico em sistemas coloidais estabilizados por macromoléculas. A área em vermelho destaca o efeito de impedimento estérico, enquanto a seta dupla esquematiza a repulsão eletrostática entre as cargas negativas. Fonte: Berni Neto, 2010.

Hipoteticamente, acredita-se que o emprego de nanopartículas de prata na revelação de impressões latentes evite a coloração de fundo ou manchas no 
material submetido à perícia, permitindo sua devolução, em bom estado, à unidade policial de origem. Outra provável vantagem trata-se da diminuição do tempo de revelação, que poderá viabilizar a realização de perícias em suportes porosos nos locais de crime. É possível, ainda, que a aplicação direta de nanopartículas de prata estabilizadas com polímeros naturais seja benéfica no sentido de simplificar o processo e excluir a necessidade de método adicional.

Baseado nas características promissoras das nanoestruturas, esse estudo buscou caracterizar nanopartículas de prata produzidas com polissacarídeos hidrofílicos extraídos da resina do cajueiro com ou sem adição de agente redutor forte. Além disso, objetivou avaliar essas formulações em sistema biológico, para determinar a segurança aos usuários, bem como avaliar preliminarmente seu potencial como agente revelador de impressões latentes. Diante do exposto, ressalta-se que esse trabalho é inovador, não apenas quanto à produção e caracterização de novos materiais, mas também quanto à aplicação dessas nanopartículas na revelação de impressões digitais latentes. 
2. OBJETIVOS 


\section{OBJETIVO GERAL}

Caracterizar e avaliar o efeito de nanopartículas de prata produzidas com polissacarídeos da goma do cajueiro, com ou sem agente redutor forte $\left(\mathrm{NaBH}_{4}\right)$, em sistema biológico, para determinar sua toxicidade e seu potencial como agente revelador de impressões digitais latentes.

\section{OBJETIVOS ESPECÍFICOS}

- Caracterizar as nanopartículas de prata por microscopia eletrônica de transmissão, para identificar a morfologia e distribuição das partículas na suspensão coloidal;

- Avaliar a capacidade de nanopartículas de prata quanto à revelação de fragmentos de impressões digitais latentes apostos em papel branco por observação visual;

- Identificar se as nanopartículas são capazes de revelar impressões digitais latentes apostas em papel branco e em lamínulas de vidro por microscopia eletrônica de varredura;

- Avaliar a toxicidade das nanopartículas, in vitro, em cultivos de células peritoneais de camundongos;

- Avaliar a toxicidade in vivo, por meio de teste autoaplicado de exposição tópica às nanopartículas. 
3. MATERIAIS E MÉTODOS 


\subsection{Tipo de estudo}

Trata-se de um estudo experimental para caracterizar e avaliar o efeito de nanopartículas de prata em células de camundongos, a fim de determinar sua toxicidade, bem como para avaliar seu potencial como agente revelador de impressões digitais latentes de um doador. $O$ estudo foi conduzido no Laboratório de Imunologia Celular da Faculdade de Medicina da Universidade de Brasília (UnB) e no Laboratório de Microscopia do Instituto de Biologia da Universidade de Brasília.

\subsection{Normas éticas}

As normas éticas para a experimentação em animais e em seres humanos (Ministério da Saúde 1996; WMA, 2013) foram plenamente obedecidas durante o desenvolvimento deste estudo. $O$ projeto de pesquisa foi submetido e aprovado pelo Comitê de Ética em Pesquisa da Faculdade de Medicina da UnB, em 26 de maio de 2011 (CEP-FM no 011/2011 - ANEXO A) e pela Comissão de Ética no Uso de Animais da Faculdade de Medicina em 29 de março de 2011 (CEUA-FM, UnBDoc no 20636/2011 - ANEXO B). O presente estudo foi elaborado em concordância com a Direção do Instituto de Identificação da Polícia Civil do Distrito Federal e desenvolvido com plena isenção ou influência de conflitos de interesse.

\subsection{Síntese das nanopartículas}

A purificação da goma foi realizada pelo método de Silva et al. (2009) com modificações descritas por Araruna et al. (2013). Soluções de goma de cajueiro (concentrações de 1,0 a $5,0 \mathrm{mg} / \mathrm{mL}$ ) e de $1 \mathrm{mM}$ de $\mathrm{AgNO}_{3}$ foram previamente preparadas sob agitação constante por $12 \mathrm{~h}$. As nanopartículas de prata estabilizadas com polissacarídeos de goma de cajueiro foram preparadas na ausência (síntese verde) ou presença (via úmida) do agente redutor borohidreto de sódio $\left(\mathrm{NaBH}_{4}\right)$ (Araruna et al. 2013). No primeiro caso, partes iguais das soluções de goma de cajueiro (concentrações de 1,0 a 5,0 mg/mL) e de $1 \mathrm{mM}$ de $\mathrm{AgNO}_{3}$ foram misturadas, sob agitação constante, por 60 minutos a $78 \pm 2^{\circ} \mathrm{C}$ de temperatura. Para obtenção das amostras por via úmida, foi adicionada uma 
alíquota de solução recém-preparada de $\mathrm{NaBH}_{4}(0,5$ ou 1\%) a uma mistura (1:1) de solução de goma de cajueiro $(1 \mathrm{mg} / \mathrm{mL})$ e de $\mathrm{AgNO}_{3}(1 \mathrm{mM})$ para a redução da prata, de $\mathrm{Ag}^{+}$para $\mathrm{Ag}^{\circ}$. A cor amarelada característica das suspensões estáveis de nanopartículas de prata foi observada por câmera digital e a obtenção dos nanocompostos foi monitorada por espectrofotometria UV-vis, por varredura nos comprimentos de onda de 300 a 600 nm (UV-3101PC, Shimadzu, Japão). Os nanocompostos produzidos pela síntese verde foram denominados AgNP-CG e, pela via úmida, $\mathrm{AgNP}-\mathrm{NaBH}_{4}$ (Tabela 1; figura 4).

Tabela 1. Concentrações das soluções de nitrato de prata, borohidreto de sódio e polissacarídeos do cajueiro utilizadas na síntese das diferentes concentrações de amostras de nanopartículas (AgNP-NaBH $\mathrm{e}_{4}$ AgNP-CG).

\begin{tabular}{c|c|c|c|c}
\hline Nanopartícula & $\begin{array}{c}\text { Concentração } \\
\text { da amostra de } \\
\mathbf{N P}(\mathbf{m g} / \mathbf{m L})\end{array}$ & $\begin{array}{c}\text { Nitrato de } \\
\text { prata }(\mathbf{m M})\end{array}$ & $\begin{array}{c}\text { Redutor } \\
\mathbf{N a B H}_{4} \\
(\mathbf{m g} / \mathbf{m L})\end{array}$ & $\begin{array}{c}\text { Polissacarídeos } \\
\text { do cajueiro } \\
(\mathbf{m g} / \mathbf{m L})\end{array}$ \\
\hline \multirow{2}{*}{ AgNP-NaBH } & 0,5 & 1 & 0,5 & 1,0 \\
& 1,0 & 1 & 1,0 & 1,0 \\
\hline \multirow{3}{*}{ AgNP-CG } & 1,0 & 1 & - & 1,0 \\
& 2,0 & 1 & - & 2,0 \\
& 3,0 & 1 & - & 3,0 \\
& 4,0 & 1 & - & 4,0 \\
\hline
\end{tabular}




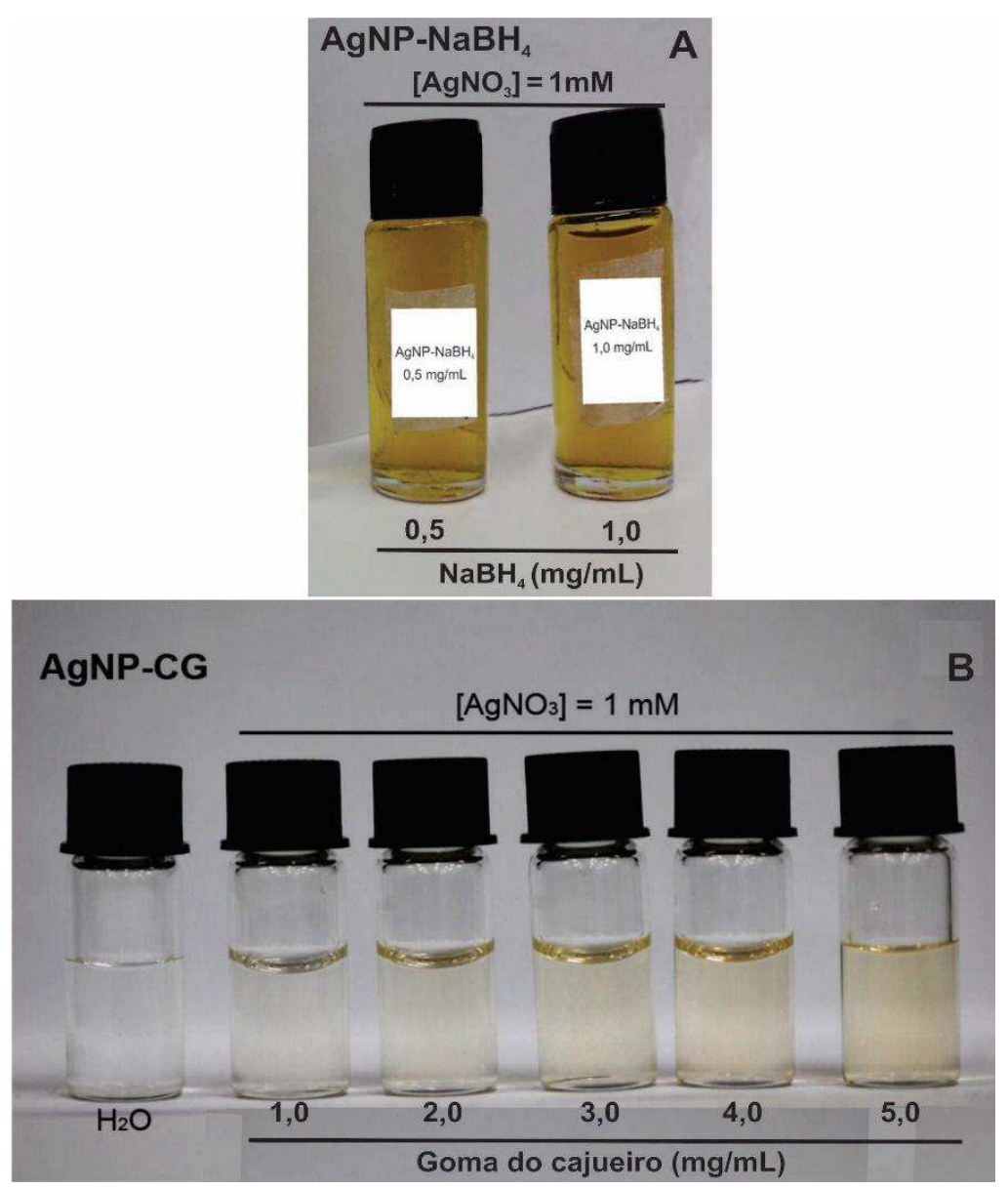

Figura 4. Fotografias das suspensões de AgNP sintetizadas com diferentes concentrações de (A) agente redutor borohidreto de sódio; (B) goma de cajueiro. Observar a gradação de cores obtida com o aumento da concentração de goma do cajueiro nos coloides formados. A água foi colocada para comparação da transparência com as diferentes concentrações das suspensões de nanopartículas.

\subsection{Caracterização morfológica das nanopartículas}

A caracterização das nanopartículas se deu por Microscopia Eletrônica de Transmissão (MET) (Microscópio Jeol, JEM 2100, Tokyo, Japan) a 200 kV. Uma alíquota de $4 \mu \mathrm{L}$ das amostras foi depositada em grade de cobre de 300 mesh, previamente tratada com solução de formol polivinil (Formvar®, SPI Supplies, USA) $0,4 \%(p / v)$ em clorofórmio. Depois de secas $\left(24 h, \pm 25^{\circ} \mathrm{C}\right)$, as grades foram introduzidas no microscópio, sob vácuo, e então focalizadas com aumento superior a 250.000 de magnificação. Os campos $(10 \%$ da área) foram fotografados e as imagens foram transferidas para o software livre GNU Image Manipulation Program (GIMP, versão 2.6.11) para a determinação do diâmetro 
das nanopartículas; foram analisadas $370 \pm 260,7$ (Me $\pm S D$ ) nanopartículas por amostra.

\subsection{Produção das impressões digitais latentes em superfície porosa}

Para avaliar se as nanopartículas de prata seriam capazes de revelar impressões digitais latentes, obtiveram-se impressões digitais de um doador voluntário adulto, do sexo feminino; por se tratar de membro integrante do estudo, eximiu-se da necessidade do termo de consentimento livre e esclarecido, segundo as normas CEP-FM. Inicialmente, o teste de revelação foi do tipo N-de-1, devido ao rendimento obtido na produção das amostras, etapa realizada no Laboratório de Biotecnologia da Universidade Federal do Piauí (UFPI), Campus Ministro Reis Velloso, Parnaíba-PI, sob a supervisão da Profa. Carla Eiras.

Informações sobre idade, doenças prévias, uso de medicamentos, dieta e aplicação de cosméticos nos sete dias anteriores à produção das impressões foram coletados, a fim de direcionar possíveis achados; não houve orientação para supressão de quaisquer hábitos do doador, visto que o objetivo foi efetivamente mimetizar a produção de impressões digitais tal como ocorre na rotina do indivíduo. Para evitar contaminação das impressões digitais, o condutor do ensaio utilizou luvas de procedimento de látex no manuseio dos papéis, vidros, pinças e demais instrumentos (Sears et al. 2012). Os ensaios foram conduzidos em ambiente com controle de temperatura e umidade, conforme Dominick et al. (2009).

As impressões digitais foram produzidas sobre papel branco (papel sulfite alcalino, gramatura de $75 \mathrm{~g} / \mathrm{m}^{2}$, Chamex® Multi Ipaper PT), por ser este o papel mais amplamente utilizado na rotina diária de grande parte dos brasileiros, especialmente para realização de impressões e fotocópias. Convencionou-se utilizar o dedo indicador direito para as análises. Foram desenhadas colunas com quadrantes para a produção das impressões. A produção das impressões latentes seguiu o procedimento descrito por Barros et al. (2013), modificado de Archer et al. (2005), de modo a simular uma condição natural de aposição de impressões latentes. Entre a produção de cada impressão, repetiu-se o procedimento listado abaixo, a fim de repor os componentes das impressões:

(a) as mãos foram esfregadas contra os antebraços, promovendo o contato direto das palmas com os antebraços, por dez segundos;

(b) com a mão direita, o doador realizou um leve toque em sua testa; 
(c) as mãos foram esfregadas uma contra a outra por mais dez segundos.

O doador depositou uma impressão digital por quadrante, pela aposição da polpa digital, com tempo de contato de 1,5 segundo, sem pressão excessiva, segundo monitoramento do condutor do ensaio, para garantir relativa consistência (adaptado de Maceo 2009); esse ensaio foi delineado de modo a não necessitar da produção de réplicas para cada amostra, uma vez que a reprodutibilidade quanto à coleta das impressões latentes foi definida em estudos anteriores (Barros et al. 2013).

\subsection{Revelação das impressões digitais latentes em superfície porosa}

A fim de demonstrar a viabilidade das impressões produzidas, conforme descrito acima, as hemipartes direitas das impressões foram utilizadas como controle positivo, sendo reveladas com solução de ninidrina, por aspersão (Tritech Forensics ${ }^{\circledR}$, LC-NIN-8, USA). Elegeu-se a ninidrina como revelador para controle positivo (Dominick et al. 2009), uma vez que se trata de reagente comumente empregado no Laboratório de Exames Papiloscópicos do Instituto de Identificação da Polícia Civil do Distrito Federal (II-PCDF) para revelação em superfícies porosas (figura 5). Além disso, essa escolha alinha-se a um dos prováveis mecanismos de ação das AgNP que é a interação eletrostática com os constituintes de carga positiva das impressões, presentes nos grupamentos amina dos aminoácidos e proteínas. 


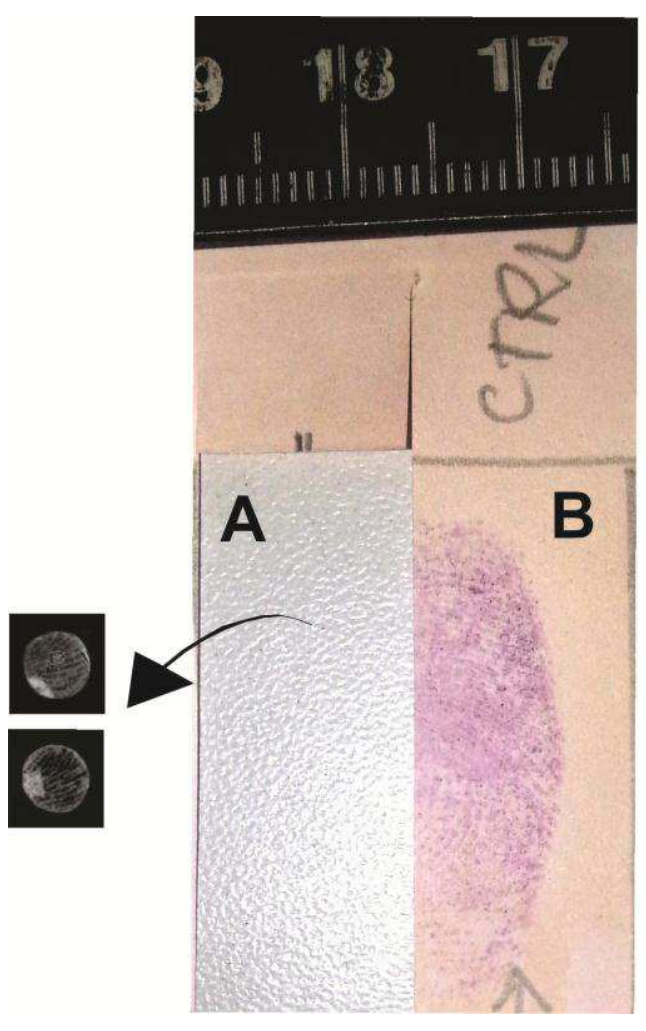

Figura 5. (A) Partes circulares do suporte poroso obtidas da hemiparte esquerda de impressão digital reveladas com as amostras de nanopartículas; (B) Hemiparte direita utilizada como controle positivo, revelada por aspersão com solução de ninidrina. Imagens obtidas com Câmera Nikon D60® sem ampliação.

Mesmo com o emprego desse método, que produziu impressões eminentemente sebáceas, houve revelação do controle com ninidrina (que revela impressões eminentemente apócrinas). Isso ocorreu porque as impressões são emulsões de constituintes oleosos e aquosos, dado o esfregaço desenvolvido anteriormente à sua produção, o qual carreou tanto suor quanto sebo e componentes exógenos.

Da região central da hemiparte esquerda dos suportes contendo as impressões, foram obtidas duas pequenas partes circulares para imersão nos sistemas nanoparticulados (figura 5); ao todo, foram utilizados 14 (quatorze) fragmentos circulares de papel contendo parte da impressão latente aposta. Os fragmentos de papel foram imersos nas suspensões de nanopartículas produzidas com emprego de agente redutor $\left(\mathrm{AgNP}-\mathrm{NaBH}_{4}\right)$ nas concentrações de 0,5 ou $1 \mathrm{mg} / \mathrm{mL}$ ou pela síntese verde (AgNP-CG) nas concentrações 1, 2, 3, 4 ou $5 \mathrm{mg} / \mathrm{mL}$; foram imersos 2 (dois) fragmentos por cada concentração.

Para cada um dos sistemas nanoparticulados, utilizaram-se dois ensaios diferentes: 1) 30 minutos de imersão dos suportes na suspensão de nanopartículas e secagem à temperatura ambiente; 2) 30 minutos de imersão dos 
suportes na suspensão de nanopartículas, seguida de lavagem em água deionizada por um minuto e secagem à temperatura ambiente (Tabela 2; figura 6).

Tabela 2. Procedimentos empregados nos experimentos de revelação de impressões latentes em suporte poroso com diferentes concentrações de AgNP-NaBH $\mathrm{H}_{4}$ e AgNP-CG.

\begin{tabular}{|c|c|c|c|c|}
\hline $\begin{array}{l}\text { Suspensão de } \\
\text { nanopartículas }\end{array}$ & $\begin{array}{c}\text { Concentração } \\
\text { da amostra de } \\
\text { NP (mg/mL) }\end{array}$ & $\begin{array}{c}\text { Imersão em NP } \\
\text { por } 30 \mathrm{~min}\end{array}$ & $\begin{array}{c}\text { Imersão em } \\
\text { água por } 1 \text { min }\end{array}$ & $\begin{array}{c}\text { Secagem a } \\
225^{\circ} \mathrm{C}\end{array}$ \\
\hline \multirow{4}{*}{ AgNP-NaBH } & \multirow{2}{*}{0,5} & Sim & - & Sim \\
\hline & & Sim & Sim & Sim \\
\hline & \multirow{2}{*}{1,0} & Sim & - & Sim \\
\hline & & Sim & Sim & Sim \\
\hline \multirow{10}{*}{ AgNP-CG } & \multirow{2}{*}{1,0} & Sim & - & Sim \\
\hline & & Sim & Sim & Sim \\
\hline & \multirow{2}{*}{2,0} & Sim & - & Sim \\
\hline & & Sim & Sim & Sim \\
\hline & \multirow{2}{*}{3,0} & Sim & - & Sim \\
\hline & & Sim & Sim & Sim \\
\hline & \multirow{2}{*}{4,0} & Sim & - & Sim \\
\hline & & Sim & Sim & Sim \\
\hline & \multirow{2}{*}{5,0} & Sim & - & Sim \\
\hline & & Sim & Sim & Sim \\
\hline
\end{tabular}




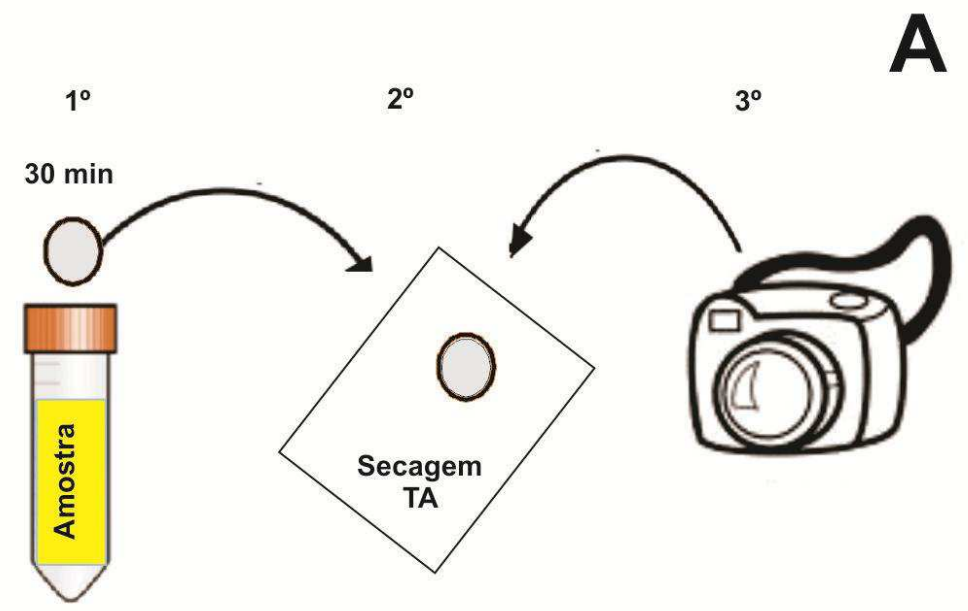

B

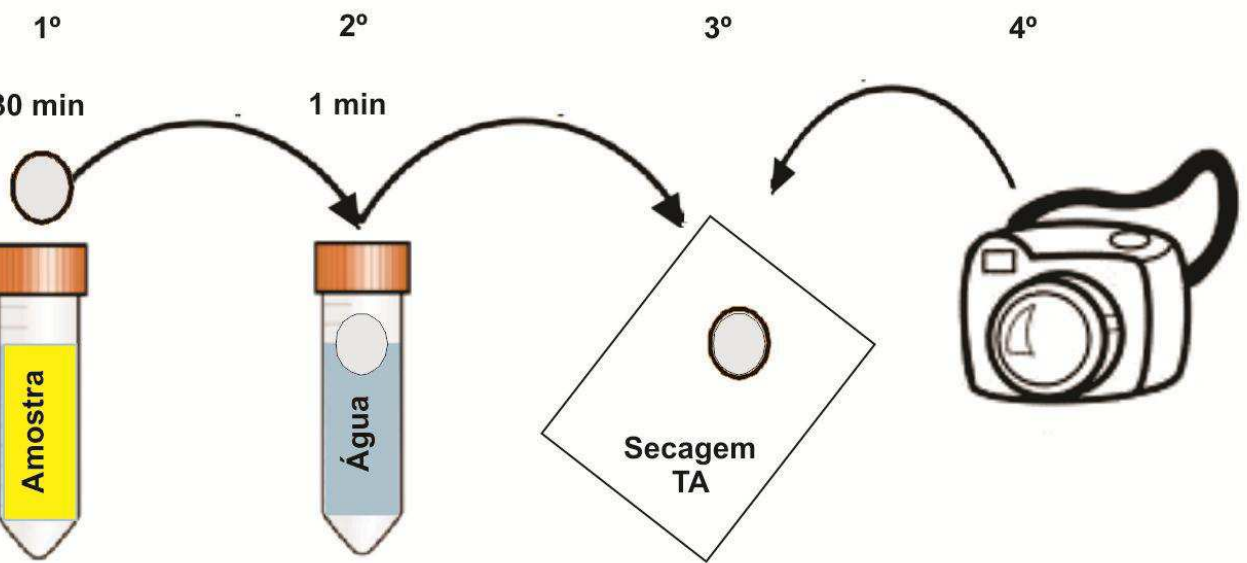

Figura 6. Representação esquemática dos procedimentos empregados na revelação de impressões latentes em suporte poroso. (A) $1^{\circ} .30$ minutos de imersão dos suportes na suspensão de nanopartículas; $2^{\circ}$. secagem a $\pm 25^{\circ} \mathrm{C} ; 3^{\circ}$. registro fotográfico das impressões reveladas. (B) $1^{\circ}$. 30 minutos de imersão dos suportes na suspensão de nanopartículas; $2^{\circ}$. lavagem em água deionizada por um minuto; $3^{\circ}$. secagem a $\pm 25^{\circ} \mathrm{C}$; $4^{\circ}$ registro fotográfico.

Após secagem, os suportes para os quais houve revelação foram fotografados com fonte de luz móvel indireta de cor branca, em modo de cena automático (figura 6). A câmera permaneceu fixa no suporte da mesa de fotografia, distante treze centímetros da superfície em que foi disposto o suporte primário, conforme protocolo do Laboratório de Processamento de Imagens Papiloscópicas do II-PCDF (Câmera Nikon D60®, Objetiva Nikon Micro Nikkor 60 $\mathrm{mm}$ 1:2.8D, resolução de 5.6 megapixels). As impressões reveladas foram fotografadas 10 min após a secagem. A fim de melhorar o contraste, equalização 
de cores, nitidez e brilho das imagens, foi utilizado o software Adobe Photoshop CS5.

O resultado da revelação foi visualizado também por Microscopia Eletrônica de Varredura (MEV) (Microscópio Jeol, modelo 7001F), em aumento de dezesseis vezes, sem metalização posterior ao tratamento.

Apenas as amostras que produziram algum grau de revelação visual foram selecionadas para os estudos de toxicidade.

\subsection{Produção e revelação das impressões digitais latentes em superfície não porosa}

A produção de impressões em lamínulas de vidro seguiu o mesmo procedimento empregado para superfície porosa. Quanto à revelação, somente foram testadas as amostras para as quais houve resultado positivo no suporte poroso, e sem restrição de volume da suspensão. Assim, foram testadas apenas as amostras AgNP-CG $3 \mathrm{mg} / \mathrm{mL}$ e AgNP-CG $5 \mathrm{mg} / \mathrm{mL}$.

As lamínulas foram imersas por 15 min nas suspensões de amostras e, em seguida, por 5 min em água deionizada (figura 7). Após secagem à temperatura ambiente, o resultado foi visualizado por MEV (Microscópio Jeol, modelo 7001F), em aumento de dezesseis vezes. Não houve metalização posterior ao tratamento, de modo a evitar resultados falsos positivos que pudessem ser erroneamente atribuídos às amostras, já que o metal contido nos sistemas nanoparticulados, nos casos de revelação, seria suficiente para permitir visualização ao MEV.

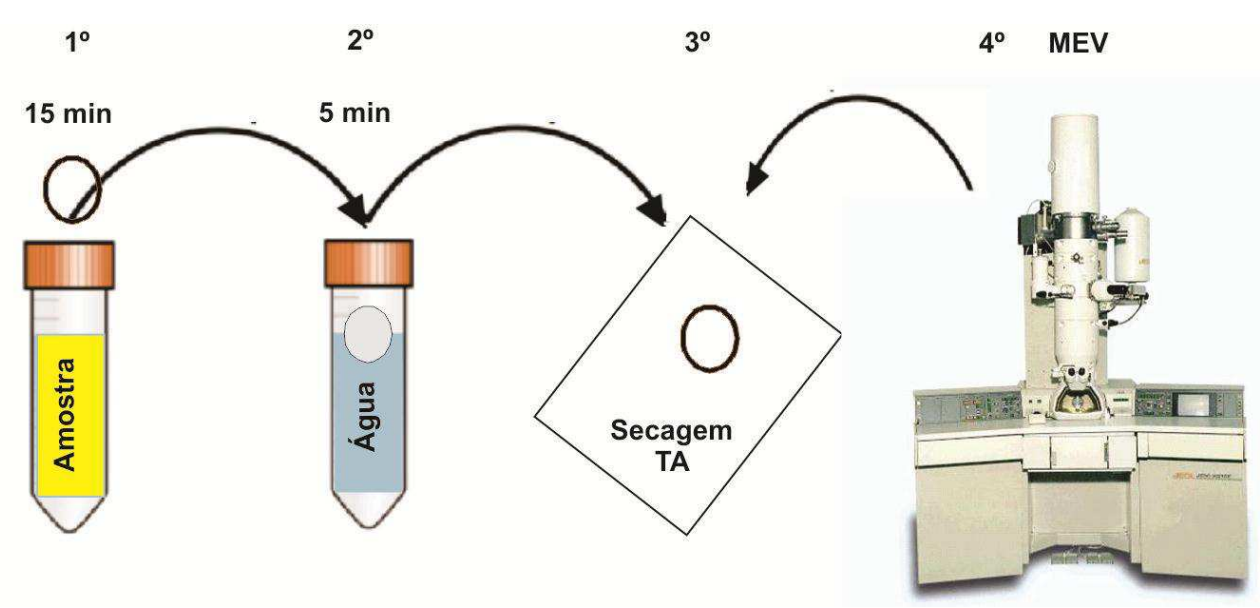

Figura 7. Representação esquemática dos procedimentos empregados na revelação de impressões latentes em lamínulas de vidro. $\left(1^{\circ}\right) 15$ minutos de imersão dos suportes na 
suspensão de nanopartículas; $\left(2^{\circ}\right)$ lavagem em água deionizada por 5 minutos; $\left(3^{\circ}\right)$ secagem à temperatura ambiente; $\left(4^{\circ}\right)$ visualização e registro fotográfico por microscopia eletrônica de varredura (MEV).

\subsection{Avaliação de citoxicidade das nanopartículas}

\subsubsection{Avaliação de toxicidade in vitro}

Por uma questão ética, somente as amostras para quais houve resultado satisfatório na revelação em suporte primário de característica porosa foram submetidas ao teste de citotoxicidade. Então, decidiu-se avaliar a citotoxicidade das amostras em células de camundongos, em detrimento de células humanas, como as obtidas de sangue, por questões de facilidade operacional. Os macrófagos peritoneais de camundongos são mais estáveis em cultura, enquanto as células humanas sanguíneas são obtidas por processo custoso e demorado.

Para avaliar o efeito das nanopartículas em células de mamíferos, foram utilizados camundongos da linhagem Swiss $(n=3)$, não isogênicos, provenientes do alojamento de animais da Faculdade de Medicina da Universidade de Brasília. Durante a fase experimental, os animais foram mantidos à temperatura ambiente $\left( \pm 25^{\circ} \mathrm{C}\right.$ ), ciclo claro/escuro de 12 horas e alimentados com ração balanceada e água potável ad libitum. Os critérios adotados para a experimentação e manutenção dos animais seguiram rigorosamente as normas estabelecidas pelo Colégio Brasileiro de Experimentação Animal (COBEA).

A células peritoneais de camundongos Swiss foram obtidas pela lavagem da cavidade peritoneal com $10 \mathrm{~mL}$ de solução Salina Fosfato Tamponada (PBS) a $4^{\circ} \mathrm{C}$ e pH 7,2. Depois de centrifugado a $400 \times \mathrm{g}$, por $10 \mathrm{~min}$, um pool de células foi suspenso em meio RPMI 1640 estéril, pH 7,2, a $4^{\circ} \mathrm{C}$, suplementado $(20 \mathrm{mM}$ de meio Hepes, $2 \mathrm{mM}$ de glutamina e 2,5 mg/dL de gentamicina) (Sigma-Aldrich, St Louis, USA) e quantificadas em hematocitômetro com solução de nigrosina (0,05\% em STF, pH 7,2); a viabilidade foi superior a 95\% (Ponte et al. 2012).

O método para avaliar possível efeito tóxico das nanopartículas (AgNPCG e AgNP-NaBH 4 ) baseou-se na sua influência sobre a capacidade de células metabolicamente ativas de reduzir o sal tetrazolium amarelo de MTT (3-[4,5dimetiltiazol-2-yl]-2,5-difenil tetrazolium brometo) a cristais de formazan de cor arroxeada. Quanto maior a formação de formazan, maior a capacidade de 
redução das células e, consequentemente, menor a toxicidade conferida pelas NP. As células peritoneais foram depositadas em placas de 96 poços $\left(2 \times 10^{5}\right.$ células/poço) em triplicata, com diferentes diluições das suspensões de nanopartículas ( $0,10 \%, 25 \%$ e $50 \%$ ), em meio RPMI. Em seguida, as células foram incubadas por uma hora a $37^{\circ} \mathrm{C}$ com $5 \%$ de $\mathrm{CO}_{2}$ em ar e, então, foram acrescidos $10 \mu \mathrm{L}$ de MTT ( $5 \mathrm{mg} / \mathrm{mL}$ ) e realizada nova incubação por mais quatro horas. Decorrido esse tempo, os poços receberam alíquotas de $50 \mu \mathrm{L}$ de dodecil sulfato de sódio (10\%) para a liberação dos cristais de formazan. Os valores das absorbâncias foram obtidos em espectrofotômetro com leitor de microplacas e filtro de $570 \mathrm{~nm}$ (SpectraMax® Plus384) e os resultados, expressos em percentagem, considerando o controle (poços sem adição de nanopartículas, ou seja, meio de cultura contendo apenas células) como tendo $100 \%$ de redução do MTT (Kückelhaus et al. 2011).

\subsubsection{Avaliação de toxicidade in vivo}

As AgNP para as quais houve revelação em papel foram testadas também quanto à toxicidade in vivo por via tópica, em teste autodirigido, pela aplicação dessas formulações sobre a pele do dorso da mão esquerda do condutor do ensaio, sem luva. A região foi observada até uma hora após a secagem das amostras na pele, bem como foi feito acompanhamento diário durante sete dias.

\subsection{Análise estatística}

Para analisar os resultados quantitativos da morfometria das nanopartículas e dos ensaios de citoxicidade, foram aplicados testes estatísticos. A normalidade das variáveis foi analisada pelo teste de Kolmogorov-Smirnov e a igualdade das variâncias, pelo teste de Bartlett; o teste de Tukey foi empregado para detectar valores discrepantes. Múltiplas comparações foram feitas pelo teste de ANOVA ou Kruskal-Wallis, para valores paramétricos ou não paramétricos, respectivamente. Para a comparação entre dois grupos dependentes, foram utilizados o teste t-pareado, para distribuições paramétricas, ou Wilcoxon, para as não paramétricas. Para avaliar se havia proporcionalidade entre aumento da concentração de goma do cajueiro e do diâmetro das nanopartículas, foi feita regressão linear. As análises e representações gráficas foram realizadas 
empregando-se o programa Prism® Software Package 5.0 (GraphPad, USA); diferenças de $p<0,05$ foram consideradas significantes. 
4. RESULTADOS 


\subsection{Caracterização morfológica das nanopartículas}

Para a caracterização das nanopartículas, foram coletadas imagens por microscopia eletrônica de transmissão e, posteriormente, tomadas as medidas dos diâmetros de $370,0 \pm 260,7$ nanopartículas por tratamento.

Os resultados mostraram que, para as amostras sintetizadas com agente redutor $\left(\mathrm{NaBH}_{4}\right)$, as medianas dos diâmetros das nanopartículas foram de $5,5 \mathrm{~nm}$ e $7,0 \mathrm{~nm}$, respectivamente, para as concentrações de $0,5 \mathrm{mg} / \mathrm{mL}$ e $1,0 \mathrm{mg} / \mathrm{mL}$, independentemente da concentração de goma do cajueiro, que permaneceu constante (Tabela 3; figuras 8 e 9) (Wilcoxon, $p=0,037$ ). Para a síntese verde, o diâmetro das nanopartículas variou de 4,5 nm para a menor concentração de goma do cajueiro $(1,0 \mathrm{mg} / \mathrm{mL})$ a $6,5 \mathrm{~nm}$ para a maior concentração $(5,0 \mathrm{mg} / \mathrm{mL})$ (Tabela 3; figuras 8 e 9). Os resultados mostraram também que o aumento do diâmetro das nanopartículas é diretamente proporcional ao aumento da concentração de goma de cajueiro (Regressão linear, $p=0,038 ; r^{2}=0,093$ ).

Tabela 3. Medianas dos diâmetros das nanopartículas para as amostras sintetizadas com agente redutor $\left(\mathrm{AgNP}-\mathrm{NaBH}_{4}\right)$ e para as amostras obtidas por síntese verde (AgNP-CG).

\begin{tabular}{c|cc|ccccc}
\hline & AgNP-NaBH & \multicolumn{5}{|c}{ AgNP-CG } \\
\hline $\begin{array}{c}\text { Concentração de } \mathrm{NaBH}_{4} \\
\text { ou goma do cajueiro } \\
(\mathbf{m g} / \mathbf{m L})\end{array}$ & 0,5 & 1,0 & 1,0 & 2,0 & 3,0 & 4,0 & 5,0 \\
\hline $\begin{array}{c}\text { Mediana do diâmetro } \\
\text { das nanopartículas } \\
(\mathbf{n m})\end{array}$ & 5,5 & 7,0 & 4,5 & 5,0 & 6,0 & 5,5 & 6,5 \\
\hline
\end{tabular}




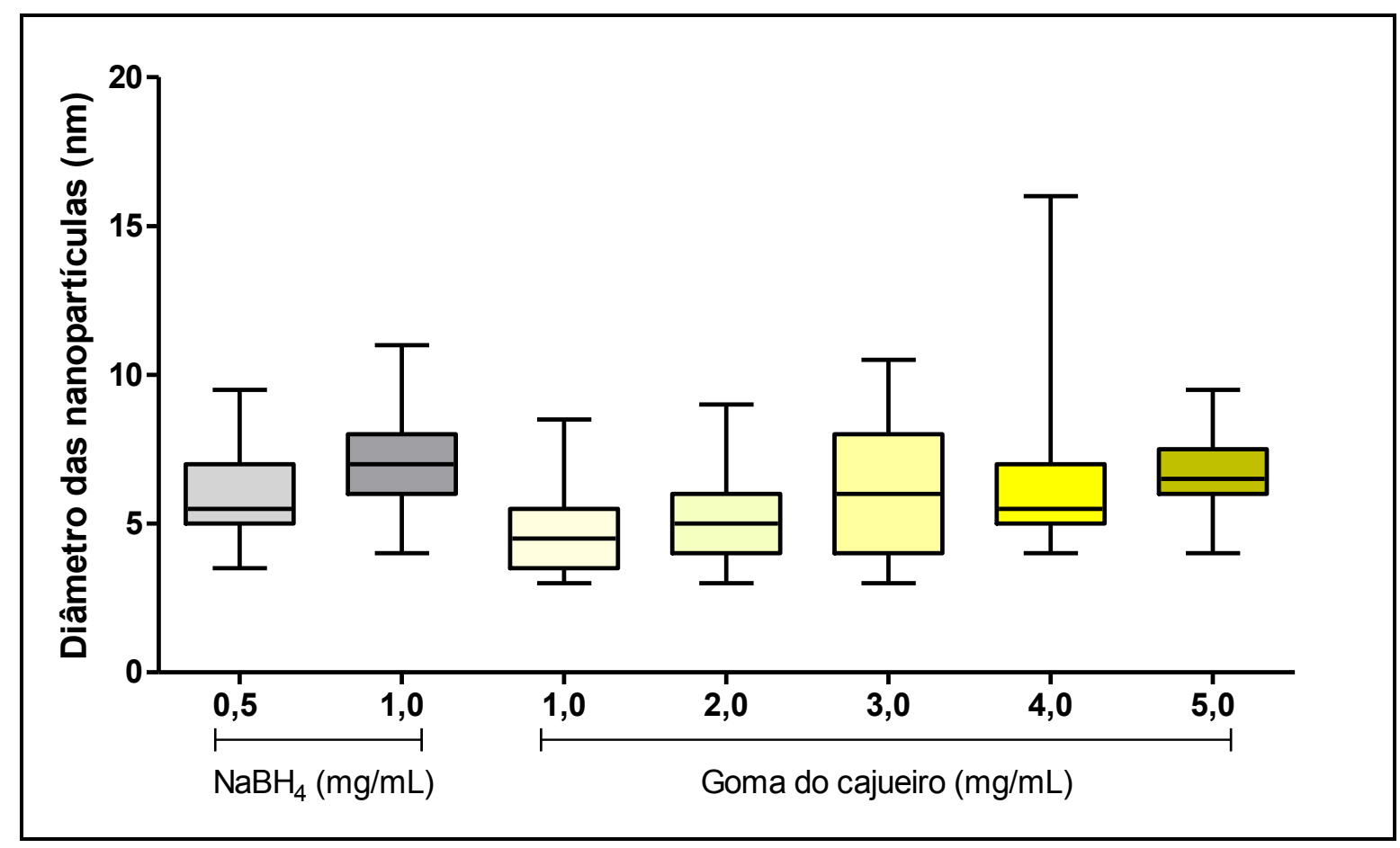

Figura 8. Distribuição do diâmetro das nanopartículas. Amostras sintetizadas com agente redutor $\left(\mathrm{NaBH}_{4}\right)$ nas concentrações de $0,5 \mathrm{mg} / \mathrm{mL}$ ou $1,0 \mathrm{mg} / \mathrm{mL}$ e amostras obtidas por síntese verde (estabilizadas apenas com goma do cajueiro) nas concentrações de 1,0 $\mathrm{mg} / \mathrm{mL}, 2,0 \mathrm{mg} / \mathrm{mL}, 3,0 \mathrm{mg} / \mathrm{mL}, 4,0 \mathrm{mg} / \mathrm{mL}$ ou $5,0 \mathrm{mg} / \mathrm{mL}$. Os diâmetros das nanopartículas aumentaram com a maior concentração de borohidreto de sódio (Wilcoxon, $p=0,037$ ) ou relação diretamente proporcional entre o diâmetro das nanopartículas e o aumento da concentração de goma de cajueiro (Regressão linear, $p=0,038$ ). Estão representadas as medianas, quartis, valores máximos e mínimos.

Observa-se, na Figura 9, que as nanopartículas exibem formato quaseesférico e distribuição homogênea, porém, com alguns pontos de agregação de nanopartículas, especialmente entre as maiores. Além disso, observou-se que a síntese com a maior concentração de borohidreto de sódio (AgNP-NaBH ${ }_{4}$ 1,0 $\mathrm{mg} / \mathrm{mL}$ ) gerou nanopartículas maiores do que aquelas com a maior concentração da goma de cajueiro pela via de síntese verde (AgNP-CG 5,0 mg/mL) (Teste $\mathrm{t}$, $0=0,019$ ). 

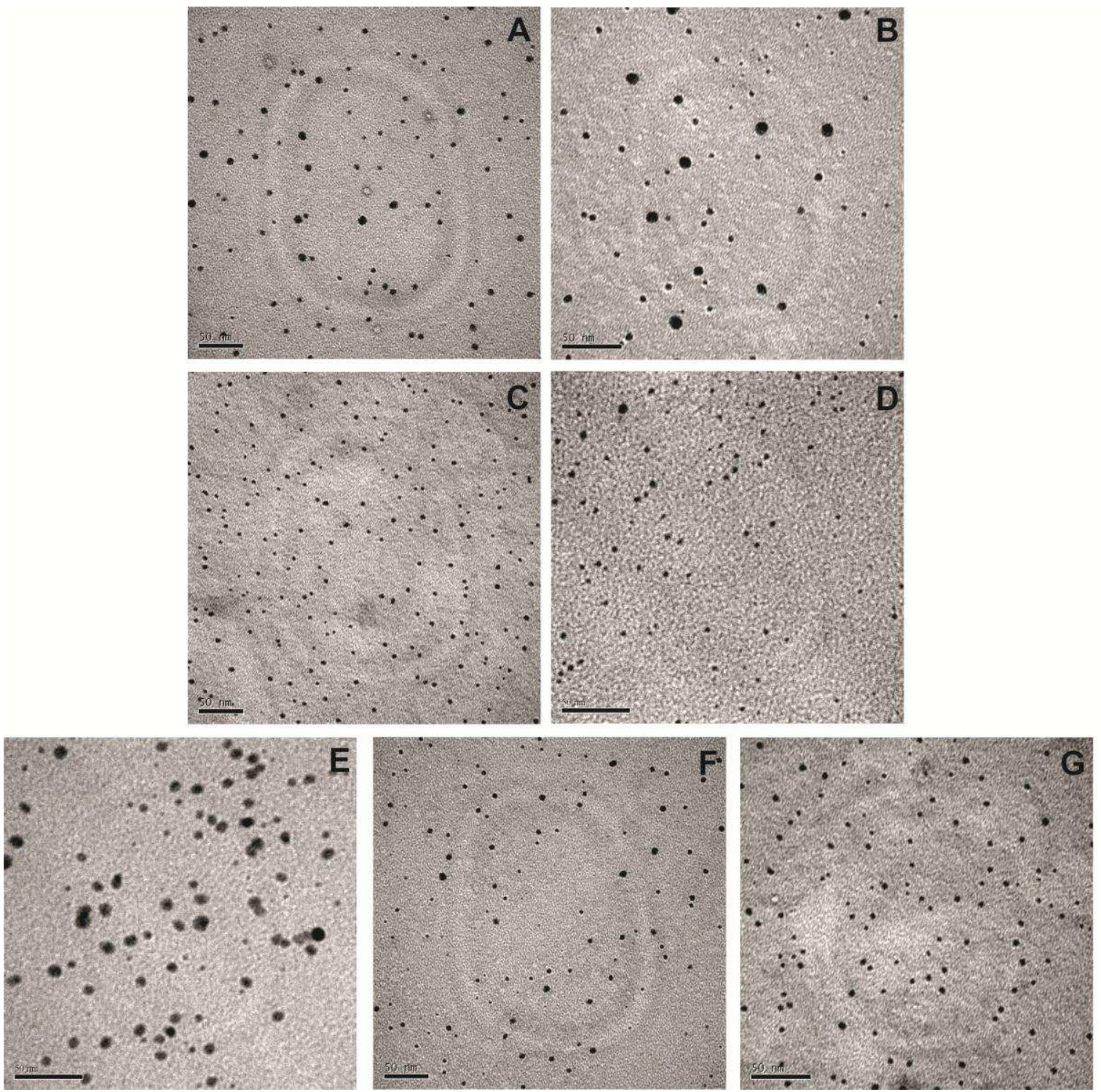

Figura 9. Eletromicrografias de transmissão das nanopartículas obtidas das amostras sintetizadas com (A) $0,5 \mathrm{mg} / \mathrm{mL}$ ou (B) $1,0 \mathrm{mg} / \mathrm{mL}$ de agente redutor $\left(\mathrm{AgNP}-\mathrm{NaBH}_{4}\right)$ e obtidas pela síntese verde (AgNP-CG) com diferentes concentrações da goma do cajueiro (C) $1,0 \mathrm{mg} / \mathrm{mL}$, (D) $2,0 \mathrm{mg} / \mathrm{mL}$, (E) $3,0 \mathrm{mg} / \mathrm{mL}$, (F) $4,0 \mathrm{mg} / \mathrm{mL}$ ou (G) $5,0 \mathrm{mg} / \mathrm{mL}$. Escala de $50 \mathrm{~nm}$.

Ressalta-se que estudos acerca da síntese e caracterização de AgNP-CG com controle de $\mathrm{pH}$ e temperatura estão sendo realizados (dados não publicados). A Figura 10 ilustra o aspecto dessas novas NP obtidas. 

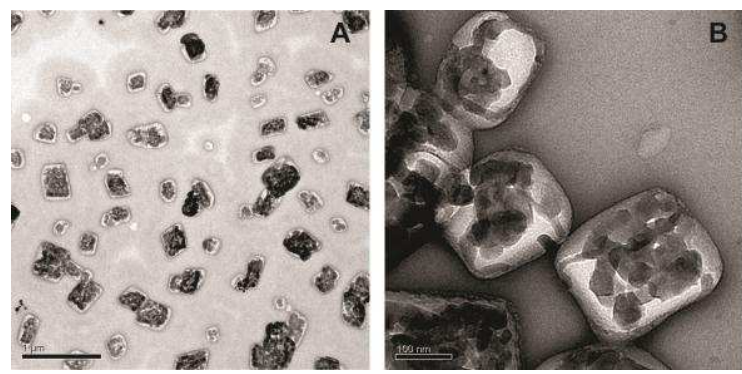

Figura 10. Eletromicrografias de transmissão de novas amostras de nanopartículas obtidas com diferentes concentrações da goma do cajueiro (AgNP-CG) (A; escala de 1 $\mu \mathrm{m})$; (B; escala de $100 \mathrm{~nm}$ ).

\subsection{Revelação de impressões digitais latentes}

\section{A. Síntese com redutor}

Conforme demonstrado na tabela 4 , dentre as suspensões sintetizadas com borohidreto de sódio, somente a de menor concentração desse redutor promoveu revelação de impressões digitais no papel branco empregado nos experimentos. Ressalta-se que o tratamento com ou sem posterior imersão em água deionizada mostrou-se revelador. Os resultados encontram-se nas fotografias A e B da Figura 11.

Tabela 4. Resultado dos testes de revelação em papel sulfite branco para as amostras sintetizadas com agente redutor $\left(\mathrm{AgNP}-\mathrm{NaBH}_{4}\right)$ ou para as amostras obtidas pela rota de síntese verde (AgNP-CG), com ou sem posterior imersão em água ultrapura.

\begin{tabular}{c|c|c|c}
\hline Nanopartícula & $\begin{array}{c}\text { Concentração da } \\
\text { amostra de } \mathbf{N P} \\
(\mathbf{m g} / \mathbf{m} L)\end{array}$ & $\begin{array}{c}\text { Revelação após 30' } \\
\text { em AgNP }\end{array}$ & $\begin{array}{c}\text { Revelação após 30' } \\
\text { em AgNP e 1' em } \\
\text { água }\end{array}$ \\
\hline AgNP-NaBH 4 & 0,5 & Sim & Sim \\
& 1,0 & Não & Não \\
\hline \multirow{2}{*}{ AgNP-CG } & 1,0 & Não & Sim \\
& 2,0 & Não & Sim \\
& 3,0 & Não & Sim \\
& 4,0 & Sim & Sim \\
& 5,0 & Sim & Não \\
\hline
\end{tabular}



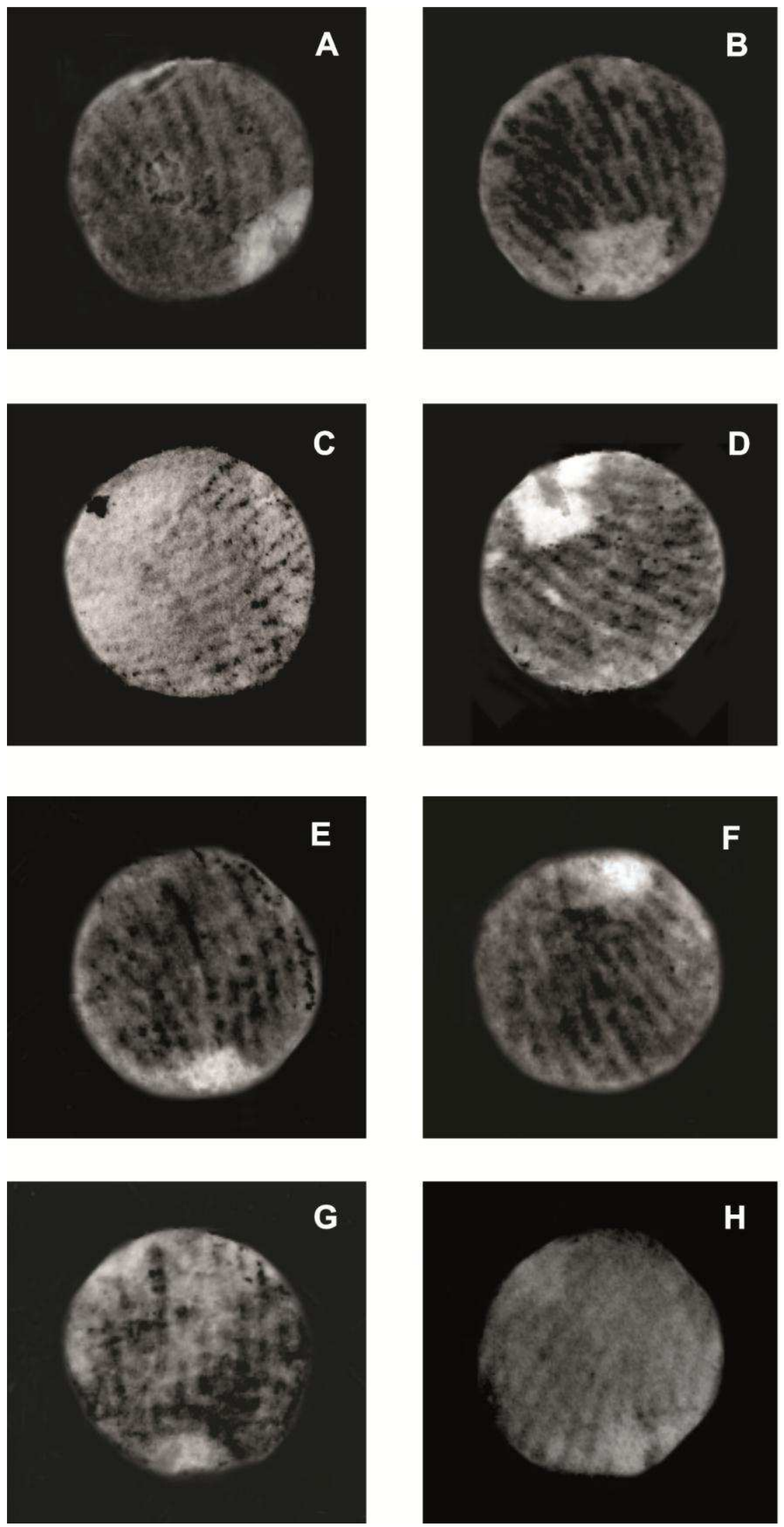

Figura 11. Fotografias da revelação de impressões digitais em papel sulfite branco. (A) imersão em suspensão de $A g N P-N_{a B H} \quad 0,5 \mathrm{mg} / \mathrm{mL}$; (B) imersão em suspensão de AgNP-NaBH ${ }_{4} \quad 0,5 \mathrm{mg} / \mathrm{mL}$ com posterior lavagem em água deionizada; (C) imersão em suspensão de AgNP-CG $1,0 \mathrm{mg} / \mathrm{mL}$ com posterior lavagem em água deionizada; (D) 
imersão em suspensão de AgNP-CG $2,0 \mathrm{mg} / \mathrm{mL}$ com posterior lavagem em água deionizada; (E) imersão em suspensão de AgNP-CG 3,0 mg/mL com posterior lavagem em água deionizada; $(F)$ imersão em suspensão de AgNP-CG 4,0 mg/mL; $(G)$ imersão em suspensão de AgNP-CG 4,0 mg/mL com posterior lavagem em água deionizada; $(\mathrm{H})$ imersão em suspensão de AgNP-CG $5,0 \mathrm{mg} / \mathrm{mL}$. As imagens foram obtidas com Câmera Nikon D60® sem ampliação.

\section{B. Síntese verde}

Para as amostras obtidas por síntese verde, todas foram capazes de revelar as impressões no suporte primário poroso, conforme tabela 4 e fotografias C, D, E, F, G e H da figura 11. Entretanto, para as amostras AgNP-CG 1, 2 ou 3 $\mathrm{mg} / \mathrm{mL}$, os resultados da revelação somente foram positivos nos tratamentos com posterior imersão em água deionizada (fotos $C, D$ e $E$ da figura 11). Ao contrário, no caso da suspensão de AgNP-CG $5 \mathrm{mg} / \mathrm{mL}$, somente o tratamento sem lavagem posterior em água deionizada mostrou revelação em papel (foto $\mathrm{H}$, figura 11). Já para a amostra AgNP-CG $4 \mathrm{mg} / \mathrm{mL}$, houve revelação para os tratamentos com ou sem posterior banho em água deionizada (fotos $F$ e $G$, figura 11). Entretanto, as impressões digitais produzidas e reveladas em papel não foram passíveis de visualização por MEV. Por esse método, visualizou-se apenas a estrutura da malha do papel sulfite alcalino branco utilizado nos experimentos de revelação (figura 12).
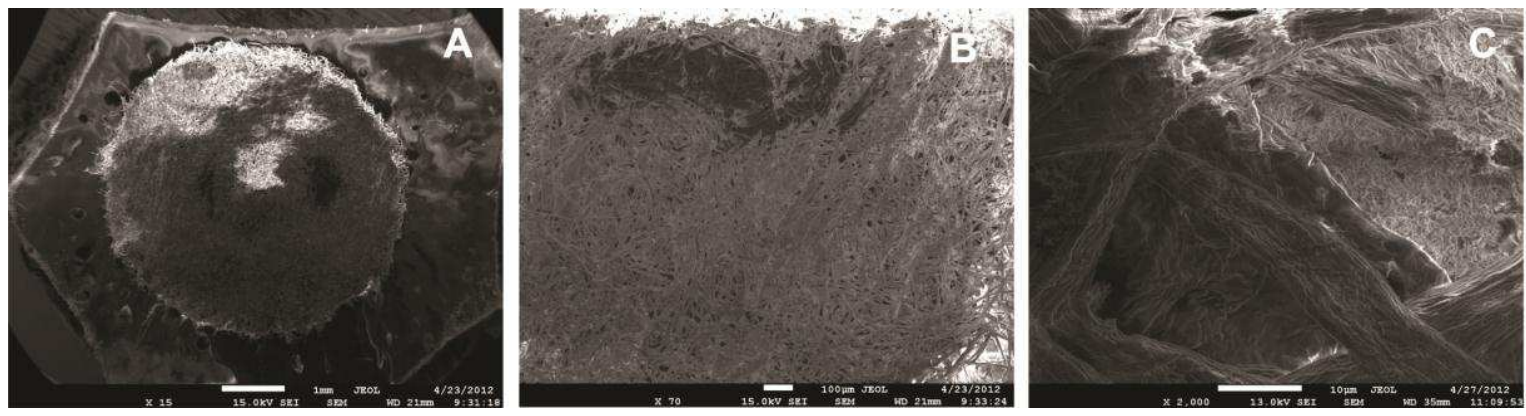

Figura 12. Eletromicrografias obtidas por microscopia eletrônica de varredura da estrutura do papel sulfite branco empregado nos experimentos de revelação de impressões digitais. Escala: $A-1 \mathrm{~mm}, \mathrm{~B}-100 \mu \mathrm{m}, \mathrm{C}-10 \mu \mathrm{m}$.

A revelação com AgNP-CG 3 mg/L e AgNP-CG 5 mg/L em lamínulas de vidro demonstrou a capacidade de revelação de impressões digitais também em superfície de característica não porosa (figura 13). Nesse caso, o método de visualização por MEV foi adequado. 


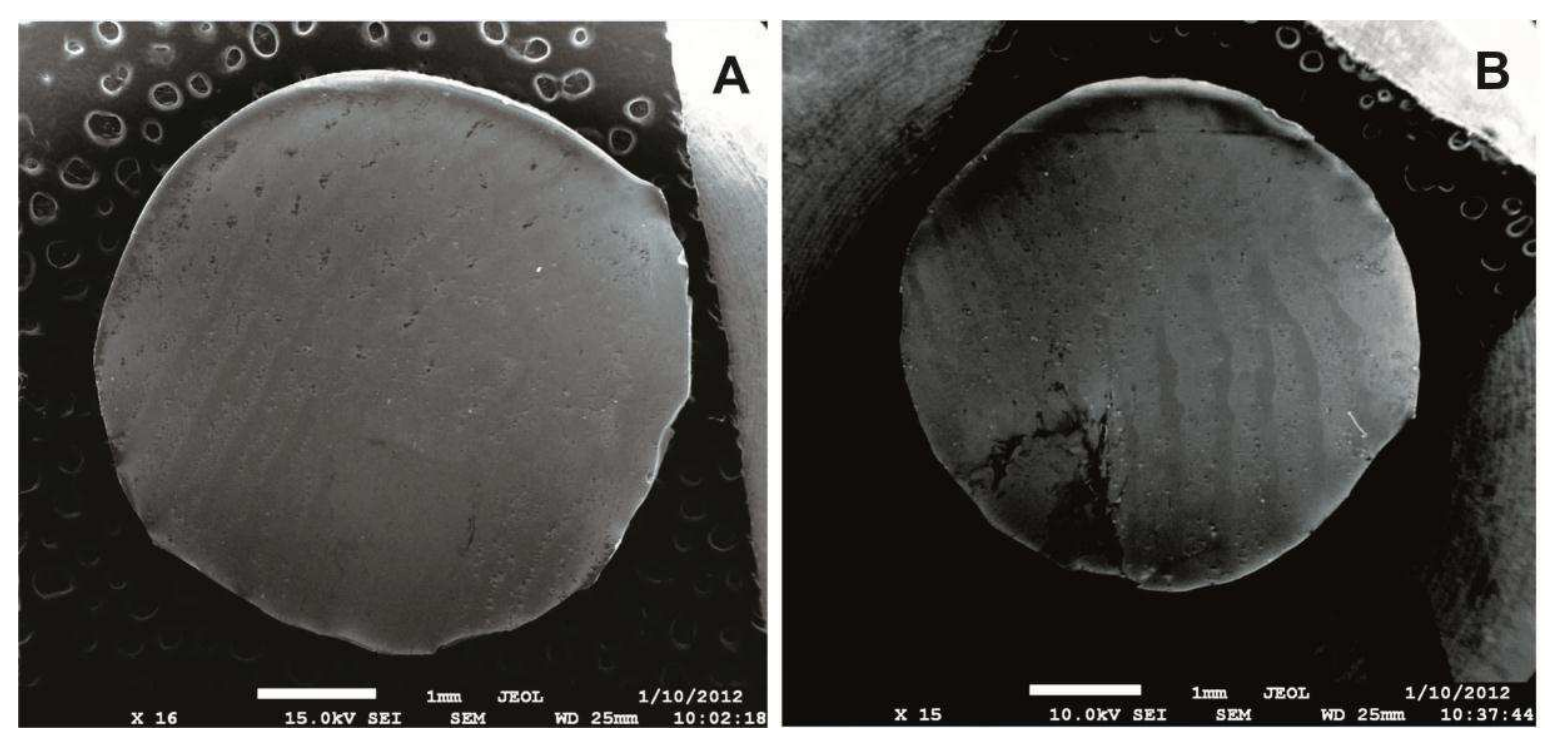

Figura 13 Eletromicrografias obtidas por microscopia eletrônica de varredura da revelação de impressões digitais em lamínulas de vidro com diferentes amostras de nanopartículas. (A) AgNP-CG $3 \mathrm{mg} / \mathrm{mL}$ e (B) AgNP-CG $5 \mathrm{mg} / \mathrm{mL}$. Aumento de 16x e 15x, respectivamente.

Destaca-se que testes de revelação com novas amostras de AgNP vêm sendo desenvolvidos, tendo sido obtidos resultados satisfatórios de revelação em papel pardo (dados não publicados), conforme ilustrado na Figura 14.
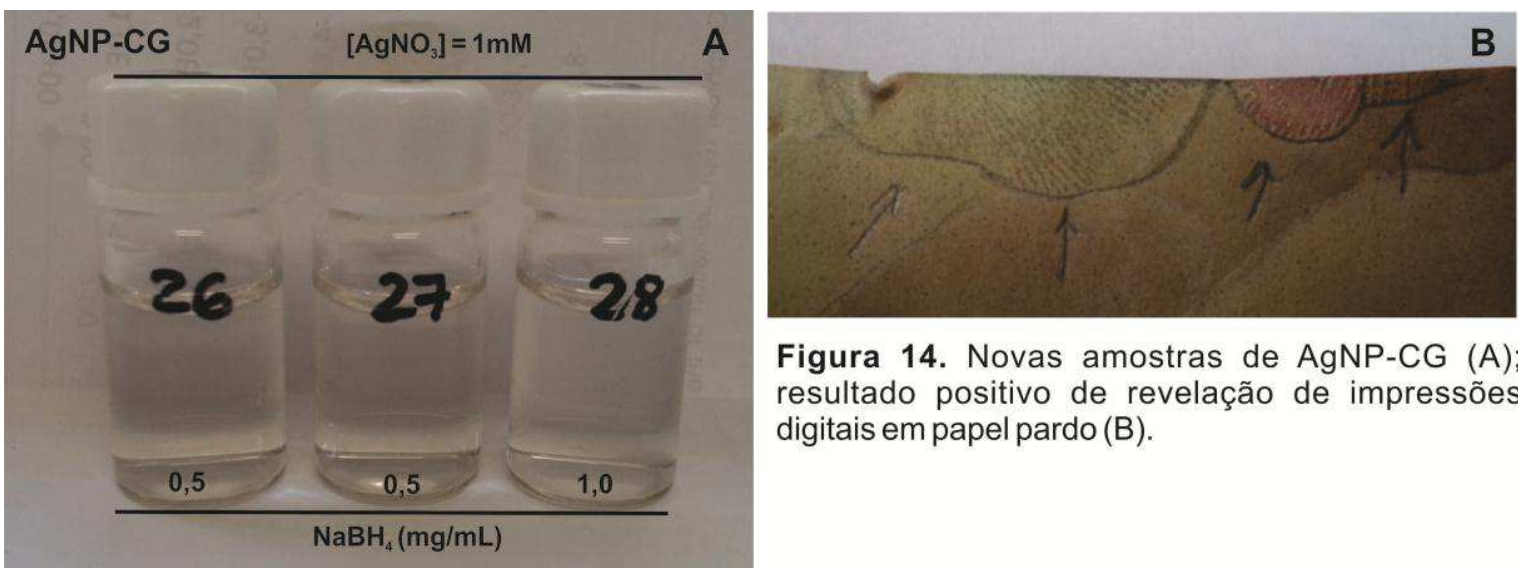

Figura 14. Novas amostras de AgNP-CG (A); resultado positivo de revelação de impressões digitais em papel pardo $(B)$.

\subsection{Avaliação de citoxicidade}

\subsubsection{Avaliação de toxicidade in vitro}

A fim de verificar se o tratamento com as nanopartículas influencia a viabilidade celular, as células peritoneais obtidas dos camundongos foram incubadas com as amostras, em diferentes diluições e, então, o percentual de 
redução do sal de MTT foi estimado a partir de resultados em absorbância por espectroscopia no comprimento de onda de $570 \mathrm{~nm}$.

\section{A. Síntese com redutor}

Quando comparado ao controle (meio RPMI sem adição de nanopartículas; 99,8\%) os resultados mostraram que a menor diluição (10\%) da suspensão de nanopartículas sintetizada com $0,5 \mathrm{mg} / \mathrm{mL}$ de borohidreto de sódio $(104,6 \%)$ não afetou a viabilidade de células peritoneais (Teste $t$ pareado, $p=0,477)$. Entretanto, para as diluições de $25 \%$ e $50 \%$ dessa amostra, observouse que a atividade metabólica das células foi diminuída em relação ao controle $(99,8 \%)$ para $42,2 \%$ ou $25,5 \%$, respectivamente (Teste t pareado, $p<0,05)$ (Tabela 5; figura 15).

Tabela 5. Percentual de redução do MTT por macrófagos peritoneais de camundongos Swiss ( $n=8)$ após incubação com diluições de 10\%, 25\% e 50\% de amostra de AgNP$\mathrm{NaBH}_{4} 0,5 \mathrm{mg} / \mathrm{mL}$ ou de suspensões de nanopartículas sintetizadas com 2, 3 ou $4 \mathrm{mg} / \mathrm{mL}$ de goma de cajueiro.

\begin{tabular}{|c|c|c|c|c|c|}
\hline \multirow{2}{*}{ Nanopartícula } & \multirow{2}{*}{$\begin{array}{c}\text { Concentração } \\
\text { da amostra } \\
(m g / m L)\end{array}$} & \multicolumn{4}{|c|}{$\begin{array}{c}\text { Mediana do \% de redução do MTT } \\
\text { Teste estatístico e valor de } p\end{array}$} \\
\hline & & $\begin{array}{l}\text { RPMI } \\
\text { (CTRL) }\end{array}$ & $10 \%$ & $25 \%$ & $50 \%$ \\
\hline AgNP-NaBH & 0,5 & 99,8 & $\begin{array}{c}104,6 \\
\text { T pareado } \\
p>0,05\end{array}$ & $\begin{array}{c}42,2 \\
\text { t pareado, } \\
p<0,0001\end{array}$ & $\begin{array}{c}25,5 \\
t \text { pareado } \\
p=0,022\end{array}$ \\
\hline \multirow{3}{*}{$A g N P-C G$} & 2,0 & 99,6 & $\begin{array}{c}51,1 \\
t \text { pareado, } \\
p<0,001\end{array}$ & $\begin{array}{c}2,3 \\
\text { Wilcoxon } \\
p=0,0078\end{array}$ & $\begin{array}{c}0,9 \\
\text { t pareado, } \\
p<0,0001\end{array}$ \\
\hline & 3,0 & 99,6 & $\begin{array}{c}14,9 \\
\text { t pareado, } \\
p<0,001\end{array}$ & $\begin{array}{c}1,6 \\
\text { Wilcoxon } \\
p=0,0313\end{array}$ & $\begin{array}{c}1,1 \\
t \text { pareado, } \\
p<0,0001\end{array}$ \\
\hline & 4,0 & 99,6 & $\begin{array}{c}24,4 \\
t \text { pareado, } \\
p=0,003\end{array}$ & $\begin{array}{c}12,0 \\
\text { t pareado, } \\
p<0,0001\end{array}$ & $\begin{array}{c}4,2 \\
\text { t pareado, } \\
p<0,0001\end{array}$ \\
\hline
\end{tabular}




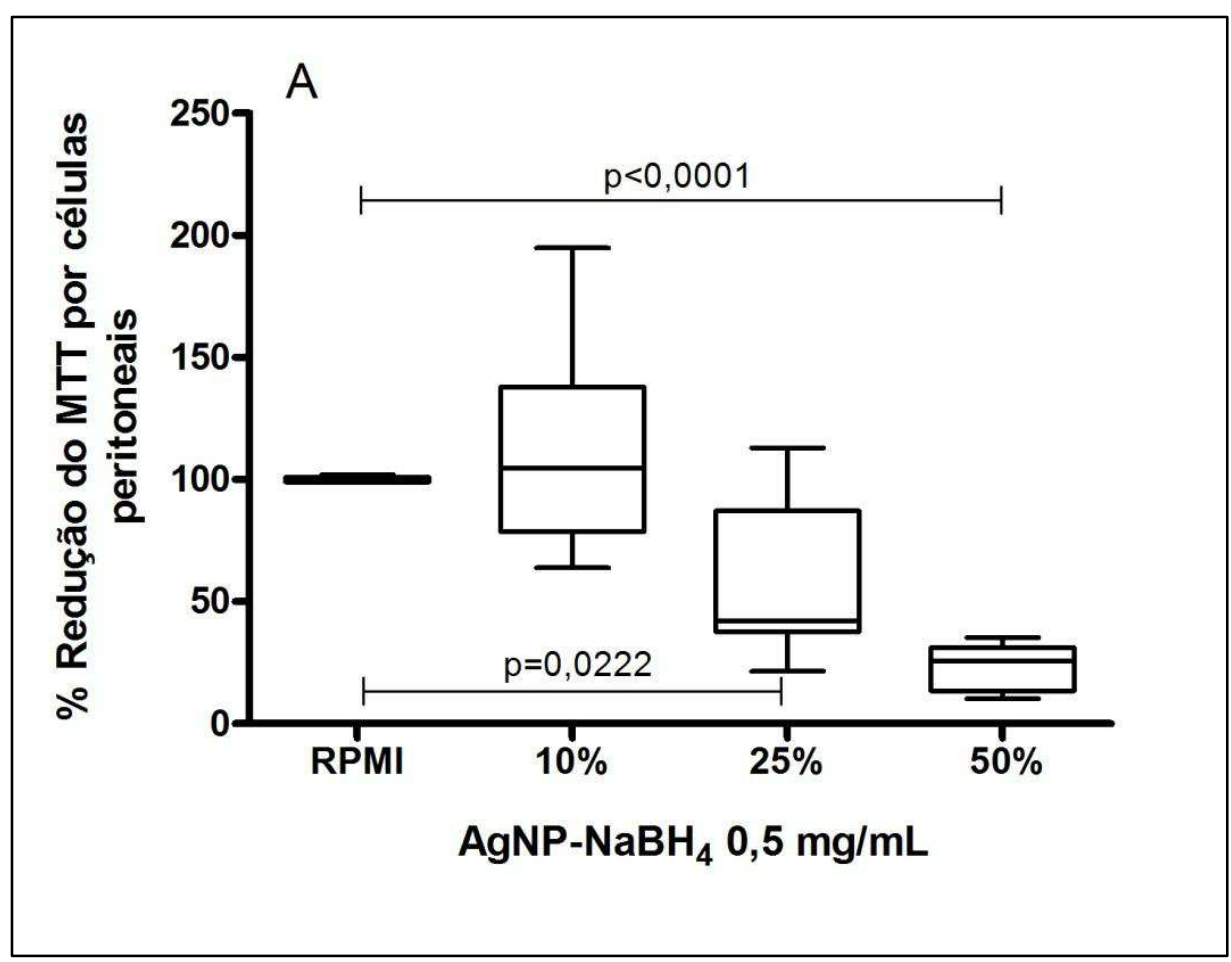

Figura 15. Percentual de redução do MTT por macrófagos peritoneais de camundongos Swiss $(n=8)$ após incubação com diluições de $10 \%, 25 \%$ ou $50 \%$ de amostra de AgNP$\mathrm{NaBH}_{4} 0,5 \mathrm{mg} / \mathrm{mL}$. A amostra, nas diluições $25 \%$ ou $50 \%$, reduziu a viabilidade dos macrófagos quando comparado ao controle (meio RPMI) (teste t pareado, $p=0,022$ e $p<0,0001$, respectivamente). A menor diluição de $\operatorname{AgNP}-\mathrm{NaBH}_{4}(10 \%)$ não afetou 0 percentual de macrófagos viáveis na comparação com o controle $(p>0,05)$. Estão representadas as medianas, quartis, valores máximos e mínimos.

\section{B. Síntese verde}

Em comparação com o controle (meio sem adição de nanopartículas; 99,6\% de redução), os resultados mostraram que, para as amostras sintetizadas com diferentes concentrações de goma do cajueiro (2, 3 ou $4 \mathrm{mg} / \mathrm{mL})$, todas as diluições diminuíram o percentual de redução do MTT, conforme demonstrado na tabela 5 e Figura 16. 

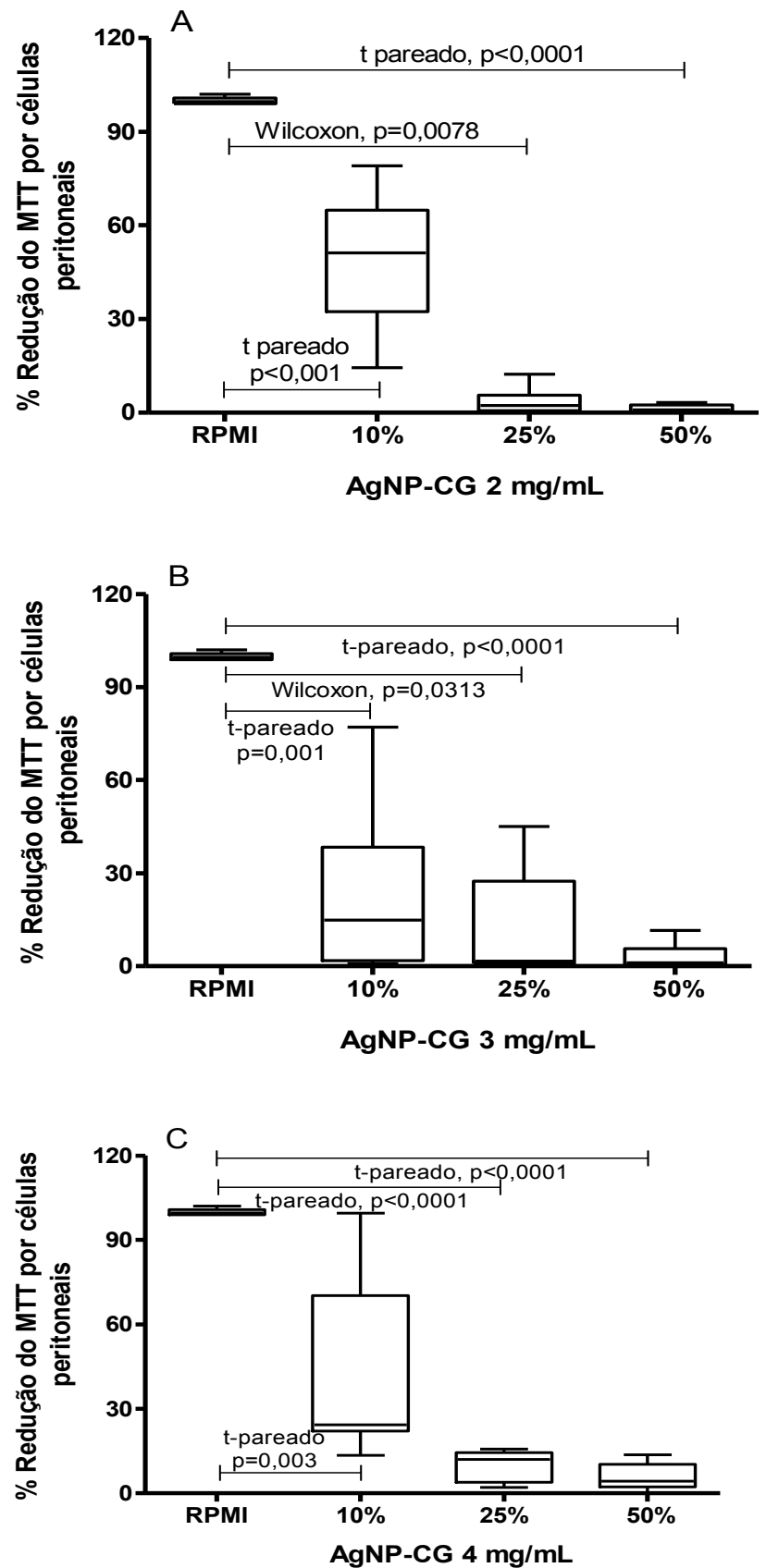

Figura 16. Percentual de redução do MTT por macrófagos peritoneais de camundongos Swiss $(n=8)$ após incubação com diluições seriadas de $10 \%, 25 \%$ ou $50 \%$ da suspensão de nanopartículas sintetizadas com 2 (A), 3 (B) ou 4 (C) $\mathrm{mg} / \mathrm{mL}$ de goma de cajueiro. As três amostras, nas diferentes diluições, causaram redução no percentual de redução do MTT $(p<0,05)$. Estão representadas as medianas, quartis, valores máximos e mínimos.

\subsubsection{Avaliação de toxicidade in vivo}

Após observação da pele até completa secagem das amostras, bem como durante os sete dias subsequentes ao teste, não foi visualizada nenhuma injúria à epiderme. 
5. DISCUSSÃO 


\subsection{Caracterização morfológica das nanopartículas}

Uma das principais dificuldades na realização do experimento de síntese de nanopartículas metálicas é a obtenção de suspensões coloidais estáveis, já que essas espécies possuem alta energia superficial, favorecendo termodinamicamente a imediata agregação para a formação de ligações metalmetal. Para evitar a agregação, a preparação de sistemas coloidais geralmente é efetuada em presença de estabilizantes, que se adsorvem às superfícies das nanopartículas, formando uma camada auto-organizada. Alguns dos estabilizantes mais eficazes são os poliméricos, como os polissacarídeos da goma do cajueiro, que possuem em sua estrutura sítios básicos de Lewis com alta afinidade pelas nanopartículas, assim como cadeias orgânicas longas, capazes de exercer efeito de impedimento estérico, evitando agregação (Melo Júnior et al. 2012). Com isso, apenas as camadas difusas das NP se sobrepõem, preservando-se a camada de Stern e a superfície da partícula, evitando-se o contato íntimo entre elas (Berni Neto 2010).

O procedimento de síntese empregado neste trabalho possibilitou a obtenção de suspensões coloidais de nanopartículas de prata de coloração amarela bastante estável. A estabilidade do sistema provém do fato de que as nanopartículas formadas permanecem em suspensão e não se agregam para a formação de partículas maiores, durante certo período de tempo (Melo Júnior et al. 2012).

O polímero extraído do cajueiro apresenta as propriedades desejáveis de atoxicidade e biodegradabilidade, além de grupos para formação de pontes de hidrogênio $(-\mathrm{OH},-\mathrm{COOH})$, de onde se obtêm fortes cargas aniônicas (Mohammadi-Samani et al. 2005), assim como características cinéticas farováveis, como a capacidade de intumescimento. Essa capacidade de absorver líquido aquoso e intumescer-se é de extrema importância, pois afeta tanto as propriedades de adesão como de aprisionamento de metais em sua matriz. Quanto maior o índice de intumescimento, mais difícil é para o metal desligar-se da rede polimérica, devido à espessa camada gelatinosa que recobre a superfície nanometálica, o que leva ao aumento do tempo de residência do metal na 
estrutura da nanopartícula (Sartori et al. 2011). Além de estabilizar o sistema, o mesmo princípio é responsável por evitar a liberação da prata da matriz polimérica após o processo de revelação, mantendo-a aderida às cristas de fricção pela ação da goma do cajueiro.

Depois de isolada, a resina passa por um processo de purificação, que consiste na transformação dos grupamentos ácido do material isolado para a forma carboxilato (Melo Júnior et al. 2012). Qualquer impureza pode servir como sítio de nucleação e promover a agregação das NP. Eletrólitos presentes no meio, ou mesmo excesso de íons $\mathrm{Ag}^{+}$podem reagir com os íons boroidreto em excesso adsorvidos nas nanopartículas, desestabilizando a suspensão coloidal. Daí a importância da utilização de água ultrapura em todo o processo, da síntese à revelação das impressões digitais (Caruso 2004).

Mais precisamente, para as nanopartículas, existe um gap entre a banda de valência e a banda de condução, diferente da estrutura de bandas do material em escala macroscópica. Essa mudança de característica de metal para isolante é observada se as partículas metálicas se tornam pequenas o suficiente para que efeitos de quantização ocorram. A energia da radiação eletromagnética necessária para promover elétrons da banda de valência para a banda de condução torna-se maior, ou seja, desloca-se para valores menores de comprimento de onda. $\mathrm{O}$ excesso de íons $\mathrm{Ag}^{+}$conduz a um aumento de tamanho dessas nanopartículas, consequentemente, para valores maiores de comprimento de onda. Esse efeito é conhecido como efeito de confinamento quântico e é responsável pela mudança de cor do sistema, como observado na coloração amarela das nanopartículas de prata, diferente da cor prateada observada quando esse metal possui dimensões macroscópicas. A diversidade de cores observada para esses materiais está relacionada às oscilações dos elétrons de condução, em ressonância com a luz incidente, denominada ressonância dos plasmons de superfície (RPS) (Solomon et al. 2007). Assim, os comportamentos ótico, eletrônico e magnético das nanopartículas metálicas e semicondutoras são estritamente dependentes do seu tamanho e formato (Rao et al. 2002; Liz-Marzán 2004). 
Os espectros de absorção de luz visível são diferentes para as moléculas que se encontram nas formas agregadas daqueles vistos para os monômeros, uma vez que a agregação altera significativamente os níveis de energia para as transições eletrônicas. Com o aumento do tamanho das partículas, a banda de plasmon de superfície torna-se mais larga e desloca-se para comprimentos de onda maiores. Além disso, uma nova banda, mais alargada, surge em comprimentos de onda maiores. Quanto maior a agregação das AgNP e, portanto, maior o seu tamanho, essa segunda banda se torna cada vez mais larga e com o máximo de absorção deslocado para maiores comprimentos de onda. Muitas nanopartículas que apresentam anisotropia de forma geram duas bandas de plasmons diferentes, as quais são relacionadas às oscilações transversais e longitudinais dos elétrons. A oscilação longitudinal é bastante sensível às razões entre as dimensões das partículas, de modo que pequenas variações da geometria esférica podem produzir mudanças expressivas nas cores (Melo Júnior et al. 2012).

Esses são os efeitos atuantes nos colóides formados que previnem a agregação das nanopartículas. Para melhorar a estabilidade frente a este fenômeno, o contato entre as partículas deve ser minimizado ao máximo. Logo, o polímero do cajueiro atua como estabilizante, ao associar o efeito estérico e o efeito eletrostático, fenômeno conhecido por estabilização eletroestérica (Caruso 2004; Goodwin 2004; Berni Neto, 2010), ao passo que o borohidreto de sódio atua como estabilizante apenas por repulsão eletrostática. Na síntese por via úmida, com a concentração fixa de goma do cajueiro, o tamanho das NP foi dependente da concentração de $\mathrm{NaBH}_{4}$ utilizada. Já na síntese verde, o aumento da concentração de goma do cajueiro levou ao aumento do tamanho das AgNP. Provavelmente isso se deu em virtude de que maior concentração de agente estabilizante causa o aumento na nucleação da prata durante a síntese, podendo progredir para maior agregação.

As nanopartículas objeto desse estudo exibem formato quase esférico, diâmetros menores que os descritos na literatura para MMD e algumas abordagens de Desposição de metal único (SMD) (Durussel et al. 2009; Stauffer 
et al. 2007; Becue et al. 2007), bem como distribuição predominantemente homogênea, porém, com alguns pontos de agregação de nanopartículas. Uma vez que partículas pequenas em suspensão oferecem uma grande área superficial para adsorção, esse fato se constitui em uma vantagem tanto para a formação das AgNP, quanto para a manutenção da estabilidade do sistema (Becue et al. 2007).

\subsection{Revelação de impressões digitais latentes}

A fim de atestar a viabilidade da impressão digital escolhida para o estudo, foram feitos controles com lamínulas de vidro, nas quais impressões foram reveladas com as amostras AgNP-CG 3mg/L e AgNP-CG 5mg/L e visualizadas por MEV. Esse teste também teve o intuito de verificar a hipótese de que as nanopartículas revelariam também em superfície lisa, uma vez que os métodos reveladores para suportes porosos, tais como MMD, SMD e suas modificações revelam também em superfície lisa (Durussel et al. 2009; Stauffer et al. 2007; Becue et al. 2007; Sametband et al. 2007).

Além disso, a escolha de apenas um doador para a produção das impressões latentes, sempre do mesmo dedo, baseou-se na premissa de limitar ao máximo o número de variáveis, de modo semelhante ao estudo de Stauffer et al. (2007).

As interações envolvidas na fabricação do papel são de origem coloidal, já que são superficiais e atuam em grandes áreas específicas. A acessibilidade de moléculas às superfícies internas das fibras constituintes do papel ocorre nos espaços vazios entre as microfibrilas elementares, desde que o tamanho dos compostos penetrantes seja superior ao dos espaços acessíveis. A dimensão, o formato e a área superficial, assim como a estereoquímica tanto das fibras do papel, quanto das moléculas, influenciam sua penetração nos capilares e reentrâncias da matriz do papel (Scott 1996).

As fibras celulósicas (figura 17) geram cargas eletrostáticas negativas em meio aquoso, tendendo a atrair e reter partículas carregadas positivamente, por atração eletrostática. Essas cargas podem ser originadas da dissociação das 
carboxilas superficiais e dos grupos ácidos sulfônicos da polpa, bem como da adsorção de substâncias como hemiceluloses, lignina dissolvida, agentes de retenção e amido catiônico presentes no meio (Scott 1996).

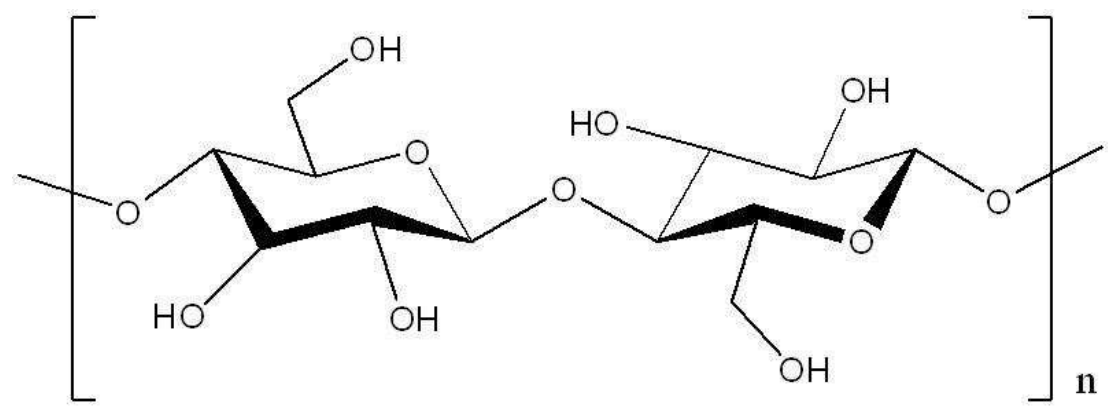

Figura 17. Representação da estrutura química da celulose. Fonte: Wang e Uchiyama (2013).

As forças de van der Waals causam atração de moléculas não carregadas eletrostaticamente, sendo efetivas somente quando próximas à fibra do papel (processos de adsorção). A afinidade de moléculas pela celulose por meio dessa atração é favorecida por uma estrutura larga e plana da molécula (Ojala 1999; Lewis 1996; Scott 1996), o que explica o fato de a goma do cajueiro não adsorver ao papel, já que não houve formação de coloração de fundo nos fragmentos de papel com impressões reveladas no presente estudo.

A celulose possui uma multiplicidade de grupos hidroxila, dos quais parte está envolvida em ligações de hidrogênio intra ou intermoleculares nas regiões amorfas e cristalinas das fibras. Entretanto, parte deles é capaz de participar de ligações de hidrogênio com o oxigênio ou o nitrogênio de radicais polares de outras moléculas (Krüsemann 1971), tais como o polímero obtido do cajueiro.

Nos processos de polpação, branqueamento ou mesmo durante a estocagem, quando entra em contato com energia radiante, a celulose pode ser oxidada. Esse processo se dá nas cadeias de celulose e hemicelulose na forma aberta, que é mais reativa. Os átomos 1, 2, 3 e 6 das unidades de anidroglicose podem ser oxidados para grupos carboxílicos, os quais representam os grupos funcionais ionizáveis que ocorrem nas fibras (Mambrim Filho e Manieri 2001; Silva et al. 2004; McDonough 1996; Rapson e Hakim 1957). No caso dos papéis 
alcalinos, como o empregado no presente estudo, o pH alcalino na faixa de 7 a 8 desloca o equilíbrio para a formação de grupos carboxílicos ( $\left.\mathrm{COO}^{-}\right)$, em detrimento de carboxilas protonadas $(\mathrm{COOH})$, conferindo às fibras carga de superfície mais negativa. Pode, ainda, haver a formação de cetonas e aldeídos (Rapson e Hakim 1957).

O papel alcalino branco empregado nos estudos é composto de amido catiônico, agente de colagem alcalina (dímero de alquil ceteno), carbonato de cálcio precipitado e agente de retenção sulfato de alumínio $\left(\mathrm{Al}_{2}\left(\mathrm{SO}_{4}\right)_{3}\right)$.

Embora na polpa ocorram mais grupos hidroxílicos que carboxílicos, esses últimos podem governar as cargas aniônicas da superfície das fibras, participando como sítios de retenção de aditivos catiônicos. Isso explica o porquê de não haver desenvolvimento de background no processo de revelação das impressões estudadas, já que não haveria interação eletrostática entre as AgNP-CG ou AgNP$\mathrm{NaBH}_{4}$, que possuem carga negativa, com a superfície do papel alcalino, que também possui carga aniônica, dada a presença de grupamentos carboxila. Os grupos hidroxila, em razão de sua grande quantidade, também conferem cargas negativas ao sistema, apesar de não serem os maiores fornecedores da carga negativa da superfície das fibras celulósicas, por apresentarem baixo grau de dissociação. Desse modo, AgNP-CG e AgNP-NaBH 4 possuem pouca afinidade por papéis de polpa branqueada e polpa contendo lignina (Scott 1996; Holmberg 1999; Marton 1980).

Sabe-se que moléculas hidrofóbicas têm maior afinidade pela fibra celulósica, por interação aos grupos hidroxila (Tsatsaroni e Liakopulou-Kyriakides 1995). Esse fator também explica a baixa afinidade da CG pelo papel, já que o polímero do cajueiro, bem como as NP formadas, apresentam caráter hidrofílico.

Quanto às lamínulas de vidro, que apresentam caráter levemente básico, esse fator possivelmente explica a não interação com as AgNP estudadas, pela repulsão eletrostática gerada.

No presente trabalho, os parâmetros de temperatura e $\mathrm{pH}$ de síntese não foram controlados, o que pode ter influenciado os processos de revelação. A formulação AgNP-NaBH 4 1,0 mg/mL não foi capaz de produzir revelação em 
papel, pois pode ter havido diferença na produção das impressões, apesar do $\mathrm{N}$ de-1 usado para aumentar a confiabilidade. Além disso, pode também ter sido prejudicada pelo fato de o estabilizante em maior concentração ter levado ao aumento no diâmetro das AgNP e, portanto, à diminuição da superfície de contato para interação com os componentes das impressões latentes.

Ademais, o aumento da estabilidade na AgNP leva a um aumento no índice de adesividade, fazendo com que as espécies de prata reduzida sejam mais fortemente aprisionadas no interior da nanoestrutura e não voltem a oxidar no meio. Espera-se que esse maior aprisionamento da prata seja devido, ainda, a um maior efeito de estabilização eletroestérica na situação em estudo. Desse modo, parece haver uma menor disponibilidade do metal em relação à área total a ser revelada, quando comparado a AgNP de mesma natureza, mas com menor concentração do agente redutor/estabilizante (CG ou $\mathrm{NaBH}_{4}$ ).

De acordo com Wilson et al. (2007), os reveladores físicos de prata revelam por meio da reação $\mathrm{Ag}^{+}+\mathrm{Fe}^{2+} \leftrightarrow \mathrm{Ag}+\mathrm{Fe}^{3+}$, que ocorre nos sítios de nucleação contidos na fração não hidrossolúvel dos componentes das impressões. O carbonato de cálcio $\left(\mathrm{CaCO}_{3}\right)$ presente no papel como aditivo (alcalinizante) pode ser o responsável pelo background observado nesse tipo de revelação. Logo, deve ser neutralizado antes da etapa do AgPD, ou os íons de prata reagirão com $\mathrm{CaCO}_{3}$, formando óxido de prata $\left(\mathrm{Ag}_{2} \mathrm{O}\right)$, composto que leva ao escurecimento do papel. A neutralização, entretanto, não deve ser feita com espécies que contenham cloretos $\left(\mathrm{Cl}^{-}\right)$, que podem ficar remanescentes no papel e reagir com a prata iônica do revelador físico, formando cloreto de prata e, assim, escurecendo todo o papel. Nesse caso, o tratamento ácido prévio recomendado é com ácido málico e a lavagem do papel em água entre o tratamento ácido e o AgPD é contra-indicado. Entretanto, no presente estudo com AgNP-CG e AgNP$\mathrm{NaBH}_{4}$, a lavagem em água foi eficiente em alguns casos, provavelmente devido ao carreamento das nanopartículas não ligadas às impressões, minimizando a coloração de fundo.

Destaca-se que o método MMD atua basicamente por duas etapas. Inicialmente, por interação eletrostática (deposição eletrolítica) do ouro coloidal 
(pela carga negativa conferida por íons citrato adsorvidos) com os componentes da impressão latente que adquirem carga positiva em baixos valores de $\mathrm{pH}$ (entre 2,5 e 2,8), ou seja, os grupamentos amina dos aminoácidos e proteínas presentes na impressão. A formação desse depósito metálico de ouro sobre a superfície das cristas da impressão latente catalisa a deposição não eletrolítica de prata (deposição metálica auto-catalítica) a partir do revelador físico (segunda etapa). Ou seja, fornece sítios de nucleação para a prata, amplificando, assim, a revelação das impressões (Choi et al. 2008).

Acredita-se que os sistemas utilizados no presente trabalho atuem na revelação pelo mesmo mecanismo de ação do ouro coloidal. Ou seja, em meio ácido, as proteínas das impressões latentes tomam carga positiva, possibilitando interação com as cargas negativas do revelador (AgNP-CG ou AgNP-NaBH 4 ). A carga negativa dessas AgNP foi verificada por meio do potencial zeta das nanopartículas (Holmberg et al. 2002; Lee 2008; Shaw 2003), que precisa ser maior ou superior (em módulo) à energia cinética fornecida pelo movimento browniano para evitar a ocorrência de agregação (Caruso 2004; Goodwin 2004). Destaca-se que, para obter revelação ainda mais satisfatória, deve-se proceder a ajustes finos de $\mathrm{pH}$ e temperatura de síntese, o que não foi feito para as NP objeto deste estudo, mas que já estão sendo controlados na produção de novas amostras (dados não publicados).

O método proposto por Schnetz e Margot (2001) difere daquele proposto por Saunders e colaboradores, essencialmente pela substituição do sistema redox. Enquanto neste o sistema é baseado em sistema ferroso/férrico, naquele, baseia-se em solução de hidroquinona. A estabilidade dessa suspensão se deve à presença de íons citrato adsorvidos às superfícies das nanopartículas. A formação da suspensão de ouro coloidal envolve a redução de $A u^{3+}$ para $A u^{0}$ pela ação do citrato de sódio como agente redutor, resultando na formação de nanopartículas com tamanho definido pela concentração de citrato de sódio presente no meio. Os íons $\mathrm{Au}^{3+}$ são introduzidos ao meio reacional a partir do ácido tetracloroáurico, que é a forma ácida do cloreto de ouro (III) (Melo Júnior et al. 2012; Choi et al. 2008). 
As nanopartículas estudadas, por serem estabilizadas por polissacarídeos do cajueiro e apresentarem carga negativa, não interagem com as estruturas do papel por forças eletrostáticas, visto haver repulsão pelas cargas da celulose aniônica no papel utilizado. Com isso, a coloração de fundo é minimizada e as AgNP-CG ou AgNP-NaBH 4 interagem majoritariamente com os constituintes das impressões digitais. Ressalta-se que uma nova abordagem relativa à funcionalização desses nanocompósitos pode ser benéfica, por meio da inserção de grupamentos hidrofóbicos que interajam com os compostos de caráter sebáceo, apolar ou hidrofóbico das impressões latentes.

A remoção de ramificações ou sítios de hidratação, a introdução de substituintes hidrofóbicos e a formação de ligações cruzadas são exemplos clássicos de modificação química a que os polissacarídeos podem ser submetidos. Alguns dos processos utilizados para esse fim resultam na obtenção de um derivado com características de gel, cuja estrutura é caracterizada pela presença de ligações cruzadas entre as cadeias do polímero (reticulações), as quais evitam a dissolução do polímero hidrofílico (Silva et al. 2006).

Artifício semelhante foi demonstrado em estudos de Sametband et al. (2007), nos quais se procedeu à funcionalização do polímero da nanopartícula, no caso o PVA, mediante o acoplamento de cadeia de octadecanotiol (AuNP-C18), a fim de permitir maior interação hidrofóbica com os constituintes das impressões.

Outras abordagens possíveis incluem a síntese de hidrogéis a partir da complexação polieletrolítica, na qual o policátion e o poliânion utilizados podem ser a quitosana e a goma de cajueiro modificada por carboximetilação, conforme descrito por Silva et al. (2004) e Maciel (2005).

Embora todas as amostras tenham possibilitado a revelação de impressões em papel, as de menor diâmetro geraram linhas visualmente mais finas, provavelmente devido a uma maior área superficial de contato com os resíduos das cristas de fricção. 


\subsection{Avaliação de citoxicidade}

\subsubsection{Avaliação de toxicidade in vivo}

Assim como ocorreu nos ensaios de revelação, houve limitação de quantidade de amostras para o teste de toxicidade in vitro. Devido ao fato de que somente as amostras que se mostrassem reveladoras seriam experimentadas quando à citotoxicidade, todas as amostras, à exceção de $\mathrm{AgNP}-\mathrm{NaBH}_{4} \quad 1,0$ $\mathrm{mg} / \mathrm{mL}$, deveriam ser submetidas ao teste. Entretanto, as amostras AgNP-CG 1,0 e 5,0 mg/mL não foram testadas, por não haver volume suficiente para este último estudo.

Entre os sistemas nanoestruturados testados, somente $\mathrm{AgNP}-\mathrm{NaBH}_{4} \quad 0,5$ $\mathrm{mg} / \mathrm{mL}$ à diluição de $10 \%$ foi atóxica. Entretanto, as diluições de 25 e $50 \%$ de AgNP-NaBH 4 0,5 mg/mL foram tóxicas. Ou seja, somente quando pequena quantidade de borohidreto de sódio foi testada não se observou toxicidade, fato que sugere a necessidade de se utilizar na formulação baixa quantidade desse agente redutor. Quanto à CG, trata-se de polímero atóxico e redutor brando, conforme explanado anteriormente. Logo, a toxicidade encontrada para as AgNP avaliadas parece ser inerente à prata, já que nas amostras obtidas por síntese ecológica houve citotoxicidade. Acredita-se que isso ocorra porque, ao adentrarem os fagócitos, os polissacarídeos das nanopartículas são metabolizados, expondo a toxicidade da prata.

Considerando-se que somente AgNP-NaBH $40,5 \mathrm{mg} / \mathrm{mL}$ (diluição de 10\%) foi atóxica, possivelmente, uma abordagem de diminuição da concentração dos agentes redutores empregados, seja $\mathrm{NaBH}_{4}$ ou $\mathrm{CG}$, resultaria em menor toxicidade, por haver menor formação de prata nanoparticulada. Observou-se tendência ao aumento do diâmetro das AgNP com o aumento da concentração do estabilizante ( $\mathrm{NaBH}_{4}$ ou CG), levando a um aumento na redução e nucleação de prata durante a síntese, o que pode ser o fator causador da maior toxicidade das AgNP com maior concentração de estabilizante/redutor. 


\subsubsection{Avaliação de toxicidade in vivo}

Apesar dos achados obtidos no teste de toxicidade in vitro, pode-se concluir que as formulações propostas neste estudo não oferecem risco ocupacional por via de exposição tópica, visto que o condutor do ensaio, após inspeção visual e pesquisa de dados na literatura sobre toxicidade de AgNP, CG e $\mathrm{NaBH}_{4}$, realizou teste autodirigido pela aplicação dessas formulações sobre a pele. Após observação durante sete dias, não foi visualizada nenhuma injúria à epiderme, sugerindo que as amostras estudadas são seguras em nível ocupacional por exposição tópica. Isso pode ser corroborado por estudos envolvendo a aplicação de compostos de prata no tratamento de queimaduras, como a sulfadiazina de prata. O uso desse composto é seguro por essa via de administração (Ito et al. 2015; Genuino et al. 2014).

A exposição por ingestão de prata, entretanto, pode levar ao quadro de Argyria generalizada, na qual ocorre uma pigmentação acinzentada da pele, devido a um aumento no nível sérico de prata e deposição de partículas na pele e seus anexos. Ressalta-se que as formulações propostas são seguras nesse aspecto, uma vez que a quantidade mínima de prata capaz de causar Argyria sistêmica é 4 a 5 gramas (Brandt et al. 2005). Esse valor somente seria atingido com exposição a volumes extraordinariamente elevados das amostras.

Esses dados, em conjunto, sugerem que as amostras estudadas são seguras em nível ocupacional por exposição tópica. Isso não exclui, porém, o uso de equipamentos de proteção nas atividades laborais. 
6. CONCLUSÕES 
Em conjunto, os resultados obtidos nesse estudo permitem as seguintes conclusões:

- As nanopartículas utilizadas nesse estudo apresentaram formato esférico e, quanto ao tamanho, os resultados mostraram que foi diretamente proporcional ao aumento na concentração do estabilizante.

- As formulações de nanopartículas sintetizadas com borohidreto de sódio $\left(\mathrm{AgNP}-\mathrm{NaBH}_{4}\right)$ e por síntese verde (AgNP-CG) foram capazes de revelar impressões digitais latentes apostas sobre papel alcalino branco mediante imersão única (AgNP-NaBH 4 0,5 mg/mL; AgNP-CG 4 ou $5 \mathrm{mg} / \mathrm{mL}$ ) ou com posterior imersão em água (AgNP-NaBH 4 0,5 mg/mL; AgNP-CG 1, 2, 3, ou $4 \mathrm{mg} / \mathrm{mL})$.

- A revelação das impressões latentes aposta em papel alcalino branco foi visualizada por observação visual, mas não por microscopia eletrônica de varredura.

- A revelação das impressões latentes aposta em lamínulas de vidro foi visualizada por microscopia eletrônica de varredura.

- Dentre as nanopartículas avaliadas nos ensaios de toxicidade in vitro, apenas a menor concentração, via síntese com borohidreto de sódio (AgNP-NaBH 4 0,5 mg/mL), não afetou o percentual de redução do MTT das células peritoneais, enquanto que as demais (AgNP-CG 2, 3, $4 \mathrm{mg} / \mathrm{mL}$ ) reduziram esse percentual, quando comparados ao controle.

- As diferentes suspensões de nanopartículas (AgNP-NaBH 0,5 $_{4}$ ou 1 $\mathrm{mg} / \mathrm{mL}$; AgNP-CG 1, 2, 3, 4 ou $5 \mathrm{mg} / \mathrm{mL}$ ) não apresentaram toxicidade tópica visual ao longo de uma semana de observação.

Os resultados obtidos nesse estudo demonstraram potencial biotecnológico dos sistemas nanoparticulados como agentes reveladores de impressões digitais latentes sobre superfície porosa e para aplicação ocupacionalmente segura aos peritos. 
7. LIMITAÇÕES E PERSPECTIVAS 
Uma vez que, nesse estudo, não foi possível realizar os testes de revelação de impressões digitais em superfície lisa para todas as amostras, estudos posteriores serão propostos, de modo a ampliar os testes em lamínulas de vidro para todas as nanopartículas. Do mesmo modo, pretende-se verificar toxicidade (MTT) para todas as concentrações de amostras para as quais se obteve revelação de impressões.

Outra limitação acerca dos métodos na presente pesquisa se deu com relação a não aplicação de escala de padronização para quantificar a revelação das impressões nas fotografias. Para tanto, propõe-se a utilização da escala NIST (National Institute of Standards and Technology) em estudos futuros.

A fim de obter resultados que contemplem maior número de variáveis, estudos devem ser executados ampliando-se o número de doadores e tempos de revelação após a produção das impressões. Além disso, pretende-se dar continuidade a estudos de síntese, caracterização e revelação de nanopartículas, com controle das variáveis $\mathrm{pH}$ e temperatura, de modo a direcionar a síntese para menores tamanhos de NP e com formatos quase-esféricos, a fim de favorecer o contato com os componentes das impressões latentes e tornar o colóide mais estável.

Outra abordagem que se planeja instituir trata-se da funcionalização das AgNP-CG, para conferir característica hidrofóbica, de modo a possibilitar interações também com os componentes sebáceos das impressões latentes. 
8. REFERÊNCIAS BIBLIOGRÁFICAS 
Araruna, FB, Quelemes, PV, de Faria BEF, Kuckelhaus SAS, Marangoni VS, Zucolotto V, da Silva, DA, Júnior JRS, Leite JRSA, Eiras CG. Synthesis and Characterization of Silver Nanoparticles Reduced and Stabilized by Cashew Tree Gum. Advanced Science, Engineering and Medicine 5 n. 8 890-893(4), August 2013.

Archer NE, Charles Y, Elliot JA, Jickells S. Changes in the lipid composition of latent fingerprint residue with time after deposition on a surface. Forensic Science International 154 224-239, 2005.

Ashbaugh DR. Quantitative-qualitative friction ridge analysis: an introduction to basic and advanced Ridgeology. Florida: CRC Press LCC 234 p, 1999.

Barros RM, Faria BEF, Kückelhaus SAS. Morphometry of latent palmprints as a function of time. Science and Justice 53 402-408, 2013.

Becue A, Champod C, Margot P. Use of gold nanoparticles as molecular intermediates for the detection of fingermarks. Forensic Science International 168(2), 169-176, 2007.

Benton M, Chua MJ, Gu F, Rowell F, Ma J. Environmental nicotine contamination in latent fingermarks from smoker contacts and passive smoking. Forensic Science International 200 28-34, 2010.

Berni Neto EA. Desenvolvimento de nanobiocompósitos contendo nanopartículas de prata para aplicações bactericidas. 112 f. Dissertação (Mestrado em Ciências) - Instituto de Física de São Carlos, Universidade de São Paulo, 2010.

Brandt D, Park B, Hoang M, Jacobe HT. Argyria secondary to ingestion of homemade silver solution. Journal of the American Academy of Dermatology 53 105-107, 2005.

Budowle B, Buscaglia J, Perlman RS. Review of the Scientific Basis for Friction Ridge Comparisons as a Means of Identification : Committee Findings and Recommendations. Research and Technology - Forensic Science Communications 8 1-16, 2006.

Caruso F. Colloids and colloid assemblies. Wiley-VCH Verlag Gmbh \& Co. KGaA Weinheim, 2004.

Champod C, Lennard C, Margot P, Stoilovic M. Fingerprints and other ridge skin impressions. Florida: CRC Press LCC 285 p, 2004.

Choi MJ, Mcdonagh AM, Maynard P, Roux C. Metal-containing nanoparticles and nano-structured particles in fingermark detection. Forensic Science International 179 87-97, 2008.

Connatser RM, Prokes SM, Glembocki, OJ, Schuler RL, Gardner CW, Lewis SA, Lewis LA. Toward surface-enhanced Raman imaging of latent fingerprints. Journal of Forensic Sciences 55 1462-1470, 2010. 
Croxton RS, Baron MG, Butler D, Kent T, Sears VG. Variation in amino acid and lipid composition of latent fingerprints. Forensic Science International 199 93-102, 2010.

Daéid NN, Buchanan HAS, Laing K. Evaluation of available techniques for the recovery of latent fingerprints from untreated plywood surfaces. Journal of Forensic Identification 59 441-465, 2009.

Day JS, Edwards HGM, Dobrowski SA, Voice AM. The detection of drugs of abuse in fingerprints using Raman spectroscopy I: latent fingerprints. Spectrochimica Acta Part A: Molecular and Biomolecular Spectroscopy 60 563-568, 2004.

de Paula RCM, Healthy F, Budd PM. Characterisation of Anacardium ccidentale: Exudate polysaccharide. Polym. Int. 45 27-35, 1998.

Dominick AJ, Daéid NN, Bleay SM, Sears V. The recoverability of fingerprints on paper exposed to elevated temperatures - Part 1: comparison of enhancement techniques. Journal of Forensic Identification 59 325-339, 2009.

Durussel P, Stauffer E, Becue A, Champod C. Margot P. Single-Metal Deposition: Optimization of this Fingermark Enhancement Technique. Journal of Forensic Identification 59(1) 80-96, 2009.

Fayaz MH, Balaji K, Girilal M, Yadav R, Kalaichelvan PH, Venketesan R. Biogenic synthesis of silver nanoparticles and their synergistic effect with antibiotics: A study against Gram-positive and Gram-negative bacteria. Nanomedicine 6 103109, 2010.

Federal Bureau of Investigation. Processing guide for developing latent prints. Washington DC: Forensic Science Communications 103 p, 2001.

Genuino GAS, Baluyut-Angeles KV, Espiritu APT, Lapitan MCM, Buckley BS. Topical petrolatum gel alone versus topical silver sulfadiazine with standard gauze dressings for the treatment of superficial partial thickness burns in adults: A randomized controlled Trial. Burns 40 1267-1273, 2014.

Girod A, Ramotowski R, Weyermann C. Composition of fingermark residue: A qualitative and quantitative review. Forensic Science International 223 10-24, 2012.

Goodwin JW. Colloids and interfaces with surfactants and polymers: an introduction. John Wiley \& Sons Ltd, 2004.

Holder Jr EH, Robinson LO, Laub JH. The Fingerprint Sourcebook. 1. ed. Washington DC, USA: U.S. Department of Justice, Office of Justice Programs, National Institute of Justice, 422 p, 2002. Disponível em: <http://www.nij.gov/ pubs-sum/225320.htm>. Acesso em: 18 novembro 2014.

Holmberg K, Jönsson B, Kronberg B, Lindman B. Surfactants and polymers in aqueous solutions. John Wiley \& Son Ltd, 2002. 
Holmberg, M. Dyes and fluorescente whitening agents. In Neimo, L. Papermaking chemistry livro 4 capítulo 14 303-320 Tappi Press, 1999.

Ito K, Saito A, Fujie T, Nishiwaki K, Miyazaki H, Kinoshita M, Saitoh D, Ohtsubo S, Takeoka S. Sustainable antimicrobial effect of silver sulfadiazine-loaded nanosheets on infection in a mouse model of partial-thickness burn injury. Acta Biomater 24:87-95, 2015.

Khanna PK, Singh N, Charan S, Subbarao VVVS, Gokhale R, Mulik, UP. Synthesis and characterization of Ag/PVA nanocomposite by chemical reduction method. Materials Chemistry and Physics 93 117-121, 2005.

Kora AJ, Sashidhar RB, Arunachalam J. Gum kondagogu (Cochlospermum gossypium): A template for the green synthesis and stabilization of silver nanoparticles with antibacterial application. Carbohydr. Polym. 82 670-679, 2010.

Krishnaraj C, Jagan EG, Rajasekar S, Selvakumar P, Kalaichelvan PT, Mohan N. Synthesis of silver nanoparticles using Acalypha indica leaf extracts and its antibacterial activity against water borne pathogens. Colloids Surf. B 76 50-56, 2010.

Krüsemann, J. Paper dyeing. Germany Farben Revue Edição especial 4 36p, 1971.

Kückelhaus CS, Kückelhaus SAS, Muniz-Junqueira MI. Influence of long-term treatment with pravastatin on the survival, evolution of cutaneous lesion and weight of animals infected by Leishmania amazonenses. Experimental Parasitology 127 658-664, 2011.

Kücken M. Models for fingerprint pattern formation. Forensic Science International $17185-96,2007$.

Lee HC, Gaensslen RE, Advances in fingerprint technology. 2. ed. Florida: CRC Press LLC 444 p, 2001.

Lee YS Self-assembly and nanotechnology: a force balance approach. John Wiley \& Sons Inc ACS, 2008.

Lewis, DM. Dyestuff-fibre interactions. International Journal of Cosmetic Science 18 123-135, 1996.

Lim AY, Ma Z, Ma J, Rowell F. Separation of fingerprint constituents using magnetic silica nanoparticles and direct on-particle SALDI-TOF-mass spectrometry. Journal of Chromatography B 879 2244-2250, 2011.

Liz-Marzán LM. Nanometals: formation and color. Materials today 7.2 26-31, 2004.

Maceo AV. Qualitative assesment of skin deformation: a pilot study. Journal of Forensic Identification 59 390-440, 2009. 
Maciel JS. Géis de goma de cajueiro e derivados com quitosana: Síntese, caracterização e ensaios preliminares em sistemas de liberação de fámacos. Tese (Doutorado em Química Inorgânica) - Centro de Ciências, Universidade Federal do Ceará, Brasil, 2005.

Mambrim Filho O, Mainieri RL, Study of carboxyl content on eucalyptus bleached kraft pulp - A process profile. Anais Nice: ISWPC, 2001.

Marton J. The role of surface chemistry in fines - cationic starch interactions. Tappi Journal 634 87-91, 1980.

Mbhele ZH, Salemane MG, Van Sittert CGC, Nedeljkovic JM, Djokovic V, Luyt AS. Fabrication and characterization of silver-polyvynil alcohol nanocomposites. Chemistry of materials 15 5019-5024, 2003.

McDonough TJ. Oxigen bleaching process. Tappi Journal 696 46-52, 1996.

Melo Júnior MA, Santos LSS, Gonçalves MC, Nogueira AF. Preparação de nanopartículas de prata e ouro: um método simples para a introdução da nanociência em laboratório de ensino. Química Nova 35 1872-1878, 2012.

Menestrina JM, lacomini M, Jones C, Gorin PAJ. Similarity of monosaccharide, oligosaccharide and polysaccharide structures in gum exudate of Anacardium ocidentale. Phytochemistry Oxford 47 715-721, 1998.

Milstone LM. Epidermal desquamation. Journal of Dermatological Science 36 131-140 2004.

Mohammadi-Samani S, Bahri-Najafi R, Yousef G. Formulation and in vitro evaluation of prednisolone buccoadhesive tablets. IL Farmaco 60 339-344, 2005.

Mong G, Petersen CE, Clauss TRW. Advanced fingerprint analysis project. Fingerprint constituents. Pacific Northwest National Laboratory Report: Richland, 1999.

Mulawka M. Postmortem Fingerprinting and Unidentified Human Remains. S.I.: s.n., 2014.

Ojala T. Chemical bonds in papermakng. In Neimo L. Papermaking Chemistry Finlândia Tappi Press Livro 4 cap. 2 18-400, 1999.

Parashar UK, Kumar V, Bera T, Saxena PS, Nath G, Srivastava SK, Giri R, Srivastava A. Study of mechanism of enhanced antibacterial activity by green synthesis of silver nanoparticles. Nanotechnology 22, 2011.

Ponte CB, Alves EAR, Sampaio RNR, Urdapilleta AAA, Kückelhaus CS, Junqueira MIM, Kückelhaus SAS. Miltefosine enhances phagocytosis but decreases nitric oxide production by peritoneal macrophages of C57BL/6 mice. International Immunopharmacology 13 114-119, 2012. 
Quelemes PV, Araruna FB, Faria BEF, Kückelhaus SAS, Silva DA, Mendonça R Z, Eiras C, Soares MJS, Leite JRSA. Development and antibacterial activity of cashew gum-based silver nanoparticles. International journal of molecular sciences 14(3) 4969-4981, 2013.

Ramotowski RS. Composition of latent print residue. In: Advances in fingerprint technology, 2nd ed., eds. Lee HC, Gaensslen RE, CRC Press, Boca Raton, FL, 63-05, 2001.

Rao CNR, Kulkarni GU, Thomas PJ, Edwards PP. Size-dependent chemistry: properties of nanocrystals. Chemistry-A European Journal 8(1) 28-35, 2002.

Rapson WH, Hakim KA. Carbonyl groups in cellulose and colour reversion. Pulp and paper magazine Canada 151-157 julho, 1957.

Ricci C, Phiriyavityopas P, Curum N, Chan KLA, Jickells S, Kazarian SG. Chemical Imaging of Latent Fingerprint Residues. Applied Spectroscopy 61 514522, 2007.

Sametband M, Shweky I, Banin U, Mandler D, Almog J. Application of nanoparticles for the enhancement of latent fingerprints. Chemical Community 11 1142-1144, 2007.

Saunders G. Multimetal deposition techique for latent fingermarks development. International Association for Identification, $74^{\text {th }}$ Annual Educational Conference, June, Pensacola, USA, 1989.

Sartori RA, de Morais LC, Consolin-Filho N, Marques DD, Gessner F. Adsorção do corante azul de metileno em partículas de argilominerais: análise dos tamanhos das partículas. Química Nova 34 584-588, 2011.

Sarubbo LA. Caracterização de um novo sistema bifásico aquoso e aplicação em extração de proteínas com coluna de discos perfurados rotativos. Doutorado. (Engenharia Química)- Faculdade de Engenharia Química da Universidade Estadual de Campinas, Campinas, 2000.

Sastri M, Ahmad A, Khan MI, Kumar R. Biosynthesis of metal nanoparticles using fungi and actinomycete. Curr. Sci. 85 162-170, 2003.

Saxena A, Tripathi RM, Zafar F, Singh P. Green synthesis of silver nanoparticles using aqueous solution of Ficus benghalensis leaf extract and characterization of their antibacterial activity. Mater. Lett. 67 91-94, 2012.

Schnetz B, Margot P. Technical Note: latent fingermarks, colloidal gold and multimetal deposition (MMD) - Optimization of the method. Forensic Science International 118 21-28, 2001.

Scott AM In: Jamieson A, Moenssens A. (Eds.). Wiley Encyclopedia of Forensic Sciences. Crime Scene Investigation. Chichester: Wiley, 2009. 
Scott WE. Coloring materials. In Principles of wet and chemistry. Atlanta. Tappi Press 45-48, 1996.

Sears VG, Bleay SM, Bandey HL. Bowman, V.J. A Methodology for Finger Mark Research. Science and Justice 52 (3) 145-160, 2012.

Shahverdi AR, Fakhimi A, Shahverdi HR, Minaian S. Synthesis and effect of silver nanoparticles on the antibacterial activity of different antibiotics against Staphylococcus aureusand Escherichia coli. Nanomedicine 3 168-171, 2007.

Sharma KV, Yngard RA, Lin Y. Silver nanoparticles: Green synthesis and their antimicrobial activities. Adv. Colloid Interface Sci. 145 83-96, 2009.

Shaw DJ. Introduction to Colloid and Surface Chemistry. Butterworth-Heinemann, Elsevier Science Ltd, 2003.

Shukla MK, Singh RP, Reddy CRK, Bhavanath J. Synthesis and characterization of agar-based silver nanoparticles and nanocomposite film with antibacterial applications. Bioresour. Technol. 107 295-300, 2012.

Silva DA, Feitosa JPA, Maciel JS, Paula HCB, de Paula RCM. Characterization of crosslinked cashew gum derivatives. Carbohydr. Polym 66 16-26, 2006.

Silva DA, Feitosa JPA, Paula HCB, de Paula RCM. Synthesis and characterization of cashew gum/acrylic acid nanoparticles. Mater. Sci. Eng. 29 437-441, 2009.

Silva DA. de Paula RCM. Feitosa JPA. de Brito ACF. Maciel JS. Paula HCB. Carboxymethylation of cashew tree exudate polysaccharide. Carbohydr. Polym 58 163, 2004.

Solomon SD, Bahadory M, Jeyarajasingam AV, Rutkowsky SA, Boritz C. Synthesis and Study of Silver Nanoparticles. Journal of Chemical Education 84(2) 322, 2007.

Stauffer E, Becue A, Singh KV, Thampi KR, Champod C, Margot P. Single-metal deposition (SMD) as a latent fingermark enhancement technique: An alternative to multimetal deposition (MMD). Forensic Science International 168 e-5-e-9, 2007.

Tadros T, Nestor J, Claire-Taelman M, Smits R. Emulsões: correlação da estabilidade física de longo prazo com medições reológicas de curto prazo. Cosmetics \& Toiletries 19 60-65, 2007.

Terasawa J, Mitsuya K, Ishii A, Tsuda T. Quantitative determination of K+, NH4+, $\mathrm{Na}+, \mathrm{Ca} 2+$ and $\mathrm{Mg} 2+$ cations in secreted human sweat by capillary zone electrophoresis. Japan Society for Analytical Chemistry 50 813-817, 2001.

Tims S, van Wamel W, Endtz HP, van Belkum A, Kayser M. Microbial DNA fingerprinting of human fingerprints: dynamic colonization of fingertip microflora challenges human host inferences for forensic purposes. International Journal of Legal Medicine 124 477-81, 2010. 
Tran VV, Tran LD, Cham TB, Vu HD, Nguyen TN, Pham DG. Nguyen, P.X. Synthesis, characterization, antibacterial and antiproliferative activities of monodisperse chitosan-based silver nanoparticles. Colloids Surf. A 360 32-40, 2010.

Tsatsaroni E, Liakopulou-Kyriakides M. Effect of enzymatic treatment on the dyeing of cotton and wool fibres whit natural dyes. Dyes and Pigments 293203 209, 1995.

Venkatpurwar V, Pokharkar V. Green synthesis of silver nanoparticles using marine polysaccharide: Study of in-vitro antibacterial activity. Mater. Lett. 65999 1002, 2011.

Wang, X, Uchiyama S. Polymers for Biosensors Construction. State of the Art in Biosensors - General Aspects. 2013. Disponível em: $<$ http://www.intechopen.com/books/state-of-the-art-in-biosensors-generalaspects/polymers-for-biosensors-construction>. Acesso em: 16 agosto 2015.

Wei D, Sun W, Qian W, Ye Y, Mac X. The synthesis of chitosan-based silver nanoparticles and their antibacterial activity. Carbohydr. Res. 344 2375-2382, 2009.

Weyermann C, Roux C, Champod C. Initial results on the composition of fingerprints and its evolution as a function of time by GC/MS analysis. Journal of Forensic Sciences 56 102-108, 2011.

Wilson JD, Cantu AA, Antonopoulos G, Surrency MJ. Examination of the steps leading up to the physical developer process for developing fingerprints. Journal of Forensic Science 52 320-329, 2007.

World Medical Association. Declaration of Helsinki, amended by 64th WMA General Assembly. Fortaleza, Brazil, October (2013). Disponível em: $<$ http://www.wma.net/en/30publications/10policies/b3/index.html.pdf?print-mediatype\&footer-right=[page]/[toPage] >. Acesso em: 20 dezembro 2015.

Zhang M, Becue A, Prudent A, Champod C, Girault HH. SECM imaging of MMDenhanced latent fingermarks. Chemical Community 3948-3950, 2007. 
9. ANEXOS 


\title{
Anexo A - Autorização do Comitê de Ética em Pesquisa em Seres Humanos CEP/FM/UnB
}

\author{
$\checkmark$ \\ UNIVERSIDADE DE BRASILIA \\ FACULDADE DE MEDICINA \\ Comitê de Ética em Pesquisa em Seres Humanos
}

\section{ANÁLISE DE PROJETO DE PESQUISA}

Registro de Projeto: CEP-FM 011/2011.

Título: "Avaliação de citotoxicidade e efeitos na revelação de impressões papilares latentes, de nanopartículas de prata estabilizadas com álcool polivinílico, quitosana e polissacarídeos isolados da goma de cajueiro: perspectivas na papiloscopia forense".

Pesquisador Responsável: Bruna Ester Ferreira de Faria.

Documentos analisados: Folha de rosto, carta de encaminhamento, declaração de responsabilidade, protocolo de pesquisa, termo de consentimento livre e esclarecido, cronograma, bibliografia pertinente e currículo (s) de pesquisador (es).

Data de entrega: 25/02/2011.

Parecer do (a) relator (a)

( X ) Aprovação

( ) Não aprovação.

Data da primeira análise pelo CEP-FM/UNB: 08/04/2011.

Data do parecer final do projeto pelo CEP-FM/UNB: 25/05/2011.

\section{PARECER}

Com base na Resolução CNS/MS n 196/96 e resoluções posteriores, que regulamentam a matéria, o Comitê de Ética em Pesquisa da Faculdade de Medicina da Universidade de Brasília decidiu APROVAR, na reunião ordinária de 25/05/2011, conforme parecer do (a) relator (a) o projeto de pesquisa acima especificado, quanto aos seus aspectos éticos.

1. Modificações no protocolo devem ser submetidas ao CEP, assim como a notificação imediata de eventos adversos graves;

2. $\mathrm{O}(\mathrm{s})$ pesquisador (es) deve (m) apresentar relatórios periódicos do andamento da pesquisa ao CEP-FM, sendo o $1^{\circ}$ previsto para 30 de novembro de 2011.

Brasília, 26 de Maio de 2011.

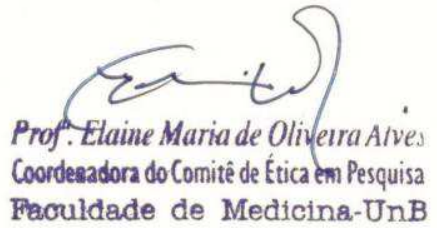




\section{Anexo B - Autorização do Comitê de Ética no Uso de Animais CEUA/FM/UnB}

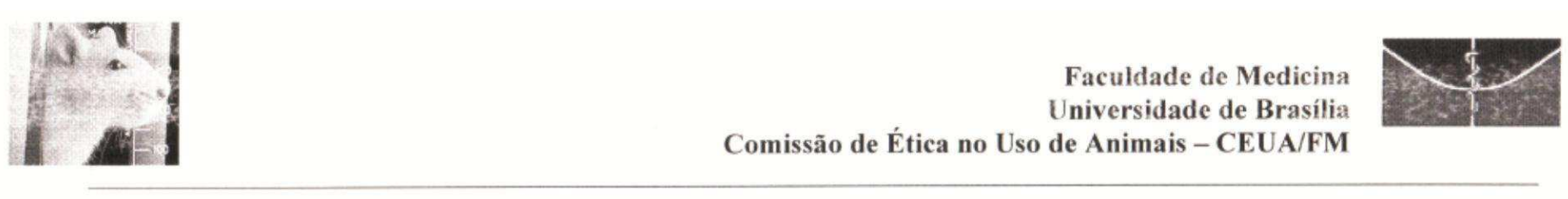

Brasília, 29 de março de 2011

\section{DECLARAÇÃO}

Declaramos que o projeto intitulado "Avaliação de Citotoxicidade e Efeitos na Revelação de Impressões Papilares Latentes, de Nanopartículas de Prata Estabilizadas com Álcool Polivinílico, Quitosana e Polissacarídeos Isolados da Goma de Cajueiro: perspectivas na papiloscopia forense", UnBDoc 20636/2011, sob responsabilidade da Profa. Selma Aparecida Souza Kuckelhaus, foi avaliado e aprovado pela Comissão de Ética no Uso de Animais (CEUA-FM) da Faculdade de Medicina da Universidade de Brasília.

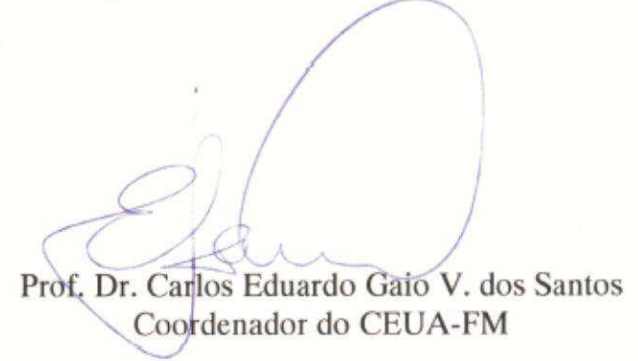

